IZA DP No. 5967

Migrant Entrepreneurs and Credit Constraints under Labour Market Discrimination

Paul Frijters

Tao Kong

Xin Meng

September 2011 


\title{
Migrant Entrepreneurs and Credit Constraints under Labour Market Discrimination
}

\author{
Paul Frijters \\ University of Queensland \\ and IZA \\ Tao Kong \\ Australian National University \\ Xin Meng \\ Australian National University \\ and IZA
}

Discussion Paper No. 5967

September 2011

\author{
IZA \\ P.O. Box 7240 \\ 53072 Bonn \\ Germany \\ Phone: +49-228-3894-0 \\ Fax: +49-228-3894-180 \\ E-mail: iza@iza.org
}

\begin{abstract}
Any opinions expressed here are those of the author(s) and not those of IZA. Research published in this series may include views on policy, but the institute itself takes no institutional policy positions.

The Institute for the Study of Labor (IZA) in Bonn is a local and virtual international research center and a place of communication between science, politics and business. IZA is an independent nonprofit organization supported by Deutsche Post Foundation. The center is associated with the University of Bonn and offers a stimulating research environment through its international network, workshops and conferences, data service, project support, research visits and doctoral program. IZA engages in (i) original and internationally competitive research in all fields of labor economics, (ii) development of policy concepts, and (iii) dissemination of research results and concepts to the interested public.
\end{abstract}

IZA Discussion Papers often represent preliminary work and are circulated to encourage discussion. Citation of such a paper should account for its provisional character. A revised version may be available directly from the author. 
IZA Discussion Paper No. 5967

September 2011

\section{ABSTRACT \\ Migrant Entrepreneurs and Credit Constraints under Labour Market Discrimination ${ }^{*}$}

We use a unique data of representative migrants and urban local workers in 15 Chinese cities to investigate entrepreneurship and credit constraints under labour market discrimination. We divide self employed into prefer to be self-employed and prefer to have a salaried job but cannot find one; and divide salaried workers into want-to-be entrepreneurs and happy-to-be salaried workers. Over 40 percent of migrant workers are either currently or want-to-be entrepreneurs. Both groups are very similar in terms of risk taking preferences and network size. Want-to-be entrepreneurs however suffer from credit constraints identified by negative financial shocks in the year before. Our back-of-envelope calculation reveals that overcoming the current level of credit constraints may be worth $2 \%$ of GDP per year direct earnings increases.

JEL Classification: L26, J14, J70

Keywords: $\quad$ entrepreneurs, credit constraints, migration, China

Corresponding author:

Xin Meng

Research School of Economics

College of Business and Economics

HW Arndt Building 25a

Australian National University

ACT 0200

Australia

E-mail: Xin.Meng@anu.edu.au

\footnotetext{
* We would like to thank Bob Gregory, David Johnston, Brian McCaig, and Russell Toth for helpful comments.
} 


\section{Introduction}

Are there credit constraints that reduce the incentives to become entrepreneurs? If so, then such constraints provide a rationale for subsidies and access to cheap loans. Many previous studies have argued credit constraints matter and distort incentives, particularly for business start-ups (Evans and Leighton, 1989; Evans and Jovanovic, 1989; Holtz-Eakin, Joulfaian and Rosen, 1994; Blanchflower and Oswald, 1998; Astero and Bernhardt, 1999; Blanchflower, 2004). Thus, in many developed countries government provides preferential access to venture capital or favorable tax treatments for small businesses (Porteretal, 2000; Djankov et al., 2002; Fonseca et al., 2007; Ardagna and Lusardi, 2008), whilst in developing countries the policy options include the Grameen Bank initiative and other micro-finance schemes (Yunus, 2006; Khander, 2005).

In this paper we look for the existence and effect of credit constraints amongst Chinese rural-to-urban migrants. What makes this group especially interesting is that they face strong overt discrimination in the wage-earning sector, ${ }^{1}$ leading to largely unexplored interactions with credit constraints. The main hypothesis we investigate is that discrimination in the salaried labour market increases the incentives to become an entrepreneur for migrants, thereby off-setting the incentive perversion of credit constraints.

Rural migrants, currently amounting to 150 million people, account for over one third of the urban Chinese workforce. Of these migrants, about a quarter are entrepreneurs, whereas the ratio for their urban 'native' counterparts is only 8 percent. It has previously been argued by Hericourt and Poncet (2007) that all private enterprises in China face high credit constraints due to a lack of access to bank loans. This should be worse for migrants since they are often legally discriminated against in the labour market (see, for example, Zhao, 2000) and their assets in their home villages cannot be used as collateral. Consistent with this, we find in our data that formal financial institutions provide no more than $2 \%$ of the initial investments made by current migrant entrepreneurs and that around a quarter of the salaried migrants want to be entrepreneurs, blaming credit constraints for their inability to leave salaried employment.

The question arises whether we can identify the intermediate steps between discrimination and the high proportions of migrants who are currently entrepreneurs or want to be an entrepreneur. In a first step, we ascertain what the expected jump in hourly income is when going from a salaried job to

\footnotetext{
${ }^{1}$ The discrimination that migrants in China face is multidimensional: most migrants do not have free access to social welfare available to urban residents. Also, in many cities they are legally barred from access to the most desirable jobs in the salaried sector.
} 
an entrepreneurial position for a migrant as opposed to a non-migrant. One main finding is that current migrant entrepreneurs earn about $30 \%$ more per hour than migrant wage-salary earners, with a much smaller gap for non-migrants.

Given this large asymmetry, we further investigate whether it is indeed credit constraints that prevent more migrants from moving to the entrepreneurial sector. Apart from simply asking the migrants about their credit constraints, we look at whether there are more negative wealth shocks amongst the group of migrants who wanted to be, but did not become, entrepreneurs. All the evidence points to an affirmative answer. The remaining 'big' question we address is the degree to which less discrimination would lead to fewer entrepreneurs.

To guide the analysis, we develop a simple descriptive model with two sectors (wage-salary and entrepreneurship), two groups of individuals (migrants and urban locals), and two markets (labour and capital markets). Migrants are discriminated against in the salaried labour market but all business startups face credit constraints. The model generates testable predictions as well as welfare implications.

The main contributions of the paper are empirical. First, we define our entrepreneurs carefully as a subset of the self-employed. In many developing and developed countries, the self-employed are made up of two quite distinct groups (cf. La Porta and Schleifer 2008): those who choose to be entrepreneurs and those from the bottom of society who could not find jobs in the paid employment sector. ${ }^{2}$ It is the first group one expects to be credit constrained, not the second. In line with this, Banerjee et al. (2009) and Karlan and Zinman (2010) report on randomised access to microcredit and find that the main benefit of more credit is for those who choose to be entrepreneurs. Using a unique survey with specially designed modules we distinguish between those who choose to be entrepreneurs and those self-employed who prefer to be wage-salary earners but could not find the job they wanted; and between wage-salary earners who want-to-be entrepreneurs and those wagesalary earners who do not. These distinctions help us to isolate the groups potentially affected by credit constraints.

Second, we use exogenous shocks to individual wealth to identify the role of credit constraints. This builds on the works of Blanchflower and Oswald (1998), Hurst and Lusardi (2004), and Wang (2010) who use inheritances and housing asset changes as positive wealth shocks to study the importance of

\footnotetext{
${ }^{2}$ For a long time, the existence of the latter group lead economists to regard selfemployment as a stepping stone to the formal sector (see Todaro, 1969; Fields,1975; Mazumdar, 1976, 1977, and Lal, 1973). This latter group is in fact too unproductive to find a formal sector job and hence should not be regarded as entrepreneurs.
} 
credit constraints. Inheritances are not randomly allocated and are to some extent anticipated, whilst regional housing price variations may relate to the regional macro-economic environment and, as such, it may affect entrepreneurship directly. Instead, we use negative events in the previous year, such as an illness or death in the family, which have significant credit constraining implications, but are unlikely to directly impact on whether one is prone to entrepreneurship.

Third, to control for possible selectivity into entrepreneurship, we draw on both self-reported information and laboratory information on trust and risk-preference, which have been found to be important predictors of entrepreneurship in previous studies (see, for example, Blau, 1985; Fairlie and Meyer, 2000; Wagner, 2005; and Qian et al., 2006; Ardagna and Lusardi, 2008). The laboratory measurements cover over a quarter of our migrant sample and included measures of risk-aversion, intelligence, and reciprocity. Want-to-be entrepreneurs are found to be very similar to current entrepreneurs in terms of risk taking preferences and the size of their network. If anything, the want-to-be entrepreneurs may be more suitable to be entrepreneurs as they are more educated. The most important differences between the two groups are that (1) the want-to-be entrepreneurs have spent less time in cities than current entrepreneurs and hence have less time to accummulate wealth in cities; and (2) they are more likely to have suffered from negative financial events in the year before the survey.

Fourth, our data allow us to directly measure the amount of initial investments and the level of credit constraint the want-to-be entrepreneurs face. We are also able to estimate the excess returns on current entrepreneurs's initial investments.

Finally, we examine whether the high rate of current and want-to-be entrepreneurship is related to the labour market discrimination against migrants by looking at whether there are more potential entrepreneurs in cities where migrants face a higher unexplained wage penalty in the salary sector.

The remainder of the paper is structured as follows: Section 2 examines the literature on entrepreneurship and credit constraints in the OECD and China and discusses particular institutional details relevant to the issue. Section 3 sets up a descriptive model in order to guide the discussion. Section 4 introduces the data and examines the aggregate differences between entrepreneurs and wage-earners. Sections 5 and 6 present empirical results. Section 7 considers the level of credit constraints and its welfare implications, and Section 8 concludes. 


\section{Literature and institutions}

\section{$2.1 \quad$ Literature}

The definition of entrepreneurs is not uniform across studies. Some include the low-earning self-employed and some do not. Depending on how entrepreneurship is defined, the characteristics of entrepreneurs vary significantly in the literature. For example, amongst the low-earning self-employed in the OECD there is an over-representation of men, migrants from poorer countries (Sanders and Nee 1996; Constant et al. 2003), and individuals who could not find a wage-earning job (Earle and Zakova 1998; Andersson and Wadensjo, 2006); the high-earning self-employed and small business owners are on the other hand more likely to be highly educated (Dawson et al. 2009), and wealthier (Nykvist, 2008; Hurst and Lusardi, 2004; Mesnard, 2004). The second group is more likely to be subject to credit constraints since many jobs in the low-earning self-employment sector, which would include jobs such as street vendors and car-screen wipers, require little capital and do not appear to be subject to any significant entry barrier.

The varying proportions of these two groups in different places at different times has led to an almost bewildering set of seemingly incompatible findings on earnings of 'entrepreneurs'. ${ }^{3}$ Even for the same groups in the same country, results differ depending on subtleties in the definition, often centering around the issue of whether one includes small businesses and whether one uses log-earnings or absolute earnings (Portes and Zhou, 1996; Hamilton, 2000).

With regard to credit constraints, the literature often finds that although the characteristics of entrepreneurs may differ from country to country, a common constraint for all countries is access to start-up capital. Thus, credit constraints have long been seen as an important factor which can make or break an entrepreneur (Evans and Leighton, 1989; Evans and Jovanovic, 1989; Holtz-Eakin, Joulfaian and Rosen, 1994; Blanchflower and Oswald, 1998; Blanchflower, 2004).

Empirically measuring credit constraints is difficult. Earlier literature often uses family wealth as a measure for the degree to which credit constraints bind and showed that those with higher family wealth are more likely to be entrepreneurs. This has, for instance, been used to rationalize why African Americans, who are on average much less wealthy than Caucasian Ameri-

\footnotetext{
${ }^{3}$ For instance: whilst the self-employed on average have been found to earn about $35 \%$ less in the U.S. in the 1980s than comparable wage-earners (Hamilton, 2000), self-employed immigrants in the U.S. earn much higher income than their counterparts in the wage-salary sector (Lofstrom, 2002).
} 
cans, are far less likely to be self-employed (Fairley and Meyer, 2000); why relatively few Mexicans are entrepreneurs in the US (Lofstrom and Wang, 2007); or why it is that the richer return migrants in Tunisia are more likely to set up new businesses (Mesnard, 2004 and Mesnard and Ravallion, 2006).

However, as Blanchflower and Oswald (1998) point out, the correlation between family wealth and becoming an entrepreneur may not be causal as both of them could be an outcome of unobserved characteristics, such as being "acquisitive". ${ }^{4}$ Blanchflower and Oswald (1998), therefore, propose a new way to investigate the causal effect, namely using a random shock to individuals' wealth to examine whether such a shock affects individuals' choice to become entrepreneurs. They used inheritances and gifts as random shocks to wealth and found that the probability of self-employment depends positively on these shocks.

Expanding on the basic methodology of Blanchflower and Oswald (1998), Hurst and Lusardi (2004) and Nanda (2010) have found that the relationship between wealth and entrepreneurship is non-linear and only occurs for the top $5 \%$ of the wealth distribution ${ }^{5}$. This calls into question whether the relation between wealth and self-employment really shows the presence of initial credit constraints rather than that being self-employed is a luxury activity of which the wealthy buy more. Furthermore, Hurst and Lusardi (2004) also find that inheritances may not be a good measure of a random shock to one's wealth as they find that both past and future inheritances predict current business entry, indicating that inheritances may capture something innate rather than a shock. The authors propose instead to use variations across regions on housing price appreciation as a random shock to households' wealth and find that such a shock has no effect on individuals' probability to start a business. On the basis of this result they conclude that in the U.S. liquidity constraints are not empirically important in deterring small business ventures. One counter argument is that increases in housing prices are not random events and will be related to general economic activity which may itself affect things like the initial costs of being an entrepreneur. This is why in our empirical

\footnotetext{
${ }^{4}$ One indication in the direction of family traits is that self-employed Americans are more likely than others to have had self-employed fathers (Hout and Rosen, 2000). In the presence of such traits, the observed correlation between wealth and self-employment may not be a sign of credit constraints but due to reverse causality.

${ }^{5}$ This empirical finding is the opposite of the prediction of Buera (2009) who has a model in which workers differ in terms of both initial wealth and aptitude for being an entrepreneur whilst facing credit constraints. In that model, there is a sorting effect in that those wage-workers with high wealth who are still not an entrepreneur are those with no comparative advantage as an entrepreneur. It seems likely that his theoretical prediction that the proportion of entrepeneurs does not go up with income at high levels of wealth would go away if one allows for entrepreneurship as a luxury good.
} 
application we will try to look for different indicators of largely unanticipated negative financial shocks.

Wang (2010) uses a very similar strategy to Hurst and Lusardi (2004) in that he looks at particular urban workers who were given the opportunity to buy their subsidised state-owned housing at relatively low prices and who subsequently were more likely than others to become an entrepreneur. Yet, Iyer et al. (2009) argue that the implementation of the relevant housing reforms was gradual and haphazard and that it is hard to find any effect of the housing reforms.

A different approach to credit constraints has been to look at aggregate indicators of the regulations applying in a country, looking at the actual costs of starting a business and the ease with which loans can be obtained (see Kerr and Nanda (2009) for a review). Porter et al. (2000), Djankov et al. (2002), Fonseca et al. (2007), and Ardagna and Lusardi (2008) for instance find that in countries with greater entry costs (such as longer waiting times for a permit), the number of entrepreneurs is lower. ${ }^{6}$

Studies of entrepreneurship in China are limited and many of them focus on rural China. In general, education is a key determinant for rural farmers choosing self-employment and the offspring of self-employed rural residents are more likely to be self-employed themselves (Zhang, et al. 2006 and Mohapatra, Rozelle, and Goodhue, 2007). In urban areas, entrepreneurs are more wealthy, more risk-taking, and have larger social networks from which to borrow (Qian et al., 2006).

\subsection{Institutions}

Over the past 20 or so years, stimulated by the fast economic growth in China, hundreds of millions of rural residents moved to cities to find jobs. The major difference with other developing countries who experienced ruralurban migration is China's household registration system, called Hukou. The Hukou system was initiated in the early 1950s. It enabled the government to sustain a rural-urban divide which was deemed to be necessary for keeping farmers producing enough agriculture product to fuel the industrialization process and to limit the cost of a very generous social welfare system implemented in cities (Perkins and Yusuf 1984; Meng, 2000; and Meng and Manning, 2010). Under the Hukou system, individuals in general were not

\footnotetext{
${ }^{6}$ Ardagna and Lusardi (2009), using a panel dataset of 44 developing and developed countries, find that more restrictive regulations disproportionately affect those with more stated business skills and contacts. Dulleck et al. (2006) find similar results and also that the greater ease of entry might have an added effect on the prior decisions of individuals to get educated.
} 
allowed to move out of their birth place. In the following decades, there was hardly any labour mobility between rural and urban regions and rural people did not have government provided social welfare, while urban people enjoyed cradle-to-grave social welfare provision.

It was not until the early 1990s, when economic growth started to pick up, which generated demand for migrant labor, that the mobility restrictions were gradually eased. Nevertheless, migrant workers have not been treated the same way as their local incumbents and, until recently, most of the discrimination against migrant workers was institutionalized. For example, migrants were only allowed to take jobs which local incumbents were unwilling to take. Even doing the same job, migrants were often paid lower earnings and were not entitled to employer contributions to various insurance schemes (West and Zhao 2000; Meng 2000; Meng and Zhang 2001; Du, Gregory and Meng 2006). Due to the institutionalized discrimination, ruralurban migrants in China are like "guest workers" who come to cities during their youth to make money and go home in their mid 30s or early 40s to settle (the estimated average length of stay of a migrant in our data is 7 years, with the self-employed staying 8.7 years and wage/salaried workers staying 6.1 years).

Perhaps as a result of the legal discrimination in the wage-salary sector, migrants are more likely to be self-employed. The 2005 one percent Intercensus population survey shows that while some $20 \%$ of migrants are selfemployed in the urban labour market, this ratio is only $11 \%$ for urban local people. Our own results (see later) show that this difference has become more pronounced. The typical migrant entrepreneur runs a small shop, a beauty salon, a cleaning agency, or a maintenance business. Becoming self-employed requires a permit and depends on having a sufficiently large network.

Credit is hard to get in China. A survey looking at 94 countries in 2000 by the World Bank found that about $80 \%$ of privately owned firms in China see financing constraints as a problem, whilst the figure is only $39 \%$ in the median country, making China the most financially constrained country in that sample (World Bank 2003). Loans from formal banks to private individuals did not become available in China until the early 2000s, with the state owned formal banks mistrusting private individuals and firms. It was estimated that by the mid 2000s, China's private companies produced more than half of its GDP, but only received 27 percent of loans (Farrell and Lund, 2006). One study found that Chinese firms, especially private firms, are among the most credit constrained firms in the world (Hericourt and Poncet, 2007). Credit is even harder to get for Chinese migrants since their lack of an Urban Hukou makes it hard to accumulate visible collateral in the cities. 


\section{A Descriptive Model}

\subsection{The model}

Our main interest is in describing the choice between being self-employed and having a salaried job, subject to the constraint that it takes a threshold amount of wealth to be able to become an entrepreneur. Our model starts with specifying the utility of a job, after which the wealth constraints are modeled, yielding a simple set of predictions about who will be entrepreneurs and what they will earn.

Take the utility derived by individual $i$ of working in job $j$ to be

$$
U_{i j}=w_{i j}+u_{2}\left(x_{i j}\right)
$$

where $w_{i j}$ denotes the hourly income individual $i$ can command in job $j$; $u_{2}\left(x_{i j}\right)$ denotes the amenity value of job $j$, which, when thinking about being salaried or self-employed, can include things like autonomy and risk. There are two types of jobs $j$, salaried (sa) and entrepreneurs (en), and the amenity value of being salaried is normalized to be zero.

Access to entrepreneurial jobs is subject to being able to raise enough the required level of start-up capital $\tilde{M}_{i}$. This level differs by individual and we here think of the costs of getting a permit, the cost of getting premises, and the cost of equipment. We can think of this amount as the outcome of a search for entrepreneurial opportunities and thus likely to be lower for individuals with many contacts and a lot of experience. The total amount of capital a person can raise is denoted as $M_{i}$ and is assumed to depend on personal characteristics, including an extended family and contacts, and all existing assets which will include the ownership of a house and longer working experience. Formally, the amount of capital someone can raise equals:

$$
\ln \left(M_{i}\right)=Z_{i}^{\prime} \gamma+v_{i}
$$

where $Z_{i}$ is the vector of characteristics and $v_{i}$ an error term. If $M_{i}<\tilde{M}_{i}$ then we will call someone credit constrained. In the data, we ask entrepreneurs how high $\tilde{M}_{i}$ was when they started their business, and we ask non-entrepreneurs how high $\tilde{M}_{i}$ is, as well as the proportion of $\tilde{M}_{i}$ that an individual thinks they can borrow from others.

Hourly returns depend on skill and Urban Hukou:

$$
w_{i j}=x_{i}^{\prime}\left(\beta_{j}+\delta_{0}\left(\text { non }-U H u k o u_{i}\right) * I_{(j=s a)}\right)+\epsilon_{i j}
$$

Here, $x_{i}^{\prime} \beta_{j}$ denotes the return to skill in the different sectors. The key testable assumption on the presence of discrimination is that $x_{i}^{\prime} \delta_{0}<0$ and 
that hence the returns for being an entrepreneur are relatively higher for migrants. ${ }^{7}$ Put equivalently, the returns to being in the salaried sector are relatively higher for Urban Hukou holders. The term $x_{i}^{\prime} \delta_{0}$ can be seen as either a form of direct taxation of non-Urban Hukou holders in the salaried sector, or else as the reduced-form result of a model with differential access to different types of jobs. We will talk about $\delta_{0}$ as the degree of discrimination.

In the empirical section, we will look for whether differential returns to skill exist (they do), whether they are relatively higher for Urban Hukou holders in the salaried labour market (they are), and whether the returns are the same for Urban Hukou holders and non-Urban Hukou holders in the entrepreneurial sector (they are close).

\subsection{Solutions and predictions}

An individual becomes an entrepreneur iff $M_{i}>\tilde{M}_{i}$ and the utility of being an entrepreneur is greater than that of being salaried, which holds when

$$
\begin{aligned}
& u_{2}\left(x_{i, e n}\right)>x_{i}^{\prime}\left(\beta_{\text {sa }}-\beta_{\text {en }}+\delta_{0}\left(\text { non }-U \text { Hukou }_{i}\right)\right)+\epsilon_{i s a}-\epsilon_{i e n} \\
& u_{2}\left(x_{i, e n}\right)>\Delta_{i},
\end{aligned}
$$

where $\Delta_{i}=x_{i}^{\prime}\left(\beta_{\text {sa }}-\beta_{\text {en }}+\delta_{0}\left(\right.\right.$ non $\left.\left.-U H u k o u_{i}\right)\right)+\epsilon_{i s a}-\epsilon_{\text {ien }}$ denotes the minimum amenity value a self-employed person must attain in order to want to be self-employed.

If we take a simple linear function for $u_{2}\left(x_{i, e n}\right)=X_{i}^{\prime} \mu+e_{i}$, where $X_{i}$ is a subset of $x_{i}$ and $e_{i}$ an error term, we get the following solution equation:

$$
P\left(j=e n \mid X_{i}, \text { UHukou }_{i}\right)=P\left(M_{i}>\tilde{M}_{i}\right) * P\left(e_{i}>\Delta_{i}-X_{i}^{\prime} \mu \mid M_{i}>\tilde{M}_{i}\right)
$$

This solution equation shows that being an entrepreneur is a function of credit constraints, the benefits of being self-employed, and the initial characteristics of the pool of individuals making the choice (migrants and urban residents).

The predictions that follow from the model which we will look for in the analyses section are:

1. (The income gap) All else equal, the hourly income-gap between entrepreneurs and salaried individuals is greater for individuals without

\footnotetext{
${ }^{7}$ Hourly income includes the excess return to the initial investment, which means wages and credit constraints will be related. This possibility will be directly explored by the inclusion of initial investment in $x_{i}^{\prime} \beta_{j}$.
} 
Urban Hukou than for individuals with Urban Hukou. This is the key testable assumption underlying the model.

2. (Urban Hukou and entrepreneurship) All else equal, individuals without Urban Hukou are more likely to be self-employed than individuals with Urban Hukou. This is because the utility benefit of being selfemployed is less for Urban Hukou holders.

3. (Wealth and self-employment) All else equal, individuals with greater amounts of initial wealth, lower capital needs, and a higher ability to borrow $\left(M_{i}\right.$ is higher) are less likely to be credit constrained and more likely to be self-employed. We will look for random negative shocks to wealth in the preceding year to help identify this channel.

4. (Start-up costs and self-employment) All else equal, actual entrepreneurs are likely to need less start-up capital $\tilde{M}_{i}$ than salaried workers who would want to be entrepreneurs, i.e. $P\left(M_{i}>\tilde{M}_{i}\right)$ is higher for individuals with lower $\tilde{M}_{i}$. Intuitively, this is because those migrants with low capital needs are more likely than those with high capital needs to meet their low needs.

The econometric problem we face is that there are major selection issues in every part of the solution equation to $P\left(j=e n \mid X_{i}, U H u k o u_{i}\right)$ : there is a strong likelihood that the initial characteristics do not have the same distribution across populations in that migrants are likely to differ from urban residents in many measured and unmeasured ways; entrepreneurs will be selfselected for their observed skills and are likely to be different from salaried workers in many unmeasured ways as well. Credit constraints are unlikely to be equally severe for everyone, leading to a further selectivity issue for the entrepreneurs.

To address the selection problems, we will rely on both random variation on sources of credit constraints and on self-reported data. We will thus look for instruments related to credit capacity $M_{i}$ that are likely to be unrelated to any of the error terms involved in $P\left(j=e n \mid X_{i}, U H u k o u_{i}\right)$ and that help identify the existence of credit constraints. We will use both standard hourly returns regressions that control for as much as possible, as well as self-reported counterfactuals to identify the structural parameters $\beta_{j}$ and $\delta_{0}$. 


\section{The Data}

\subsection{Survey and sample}

The data used in this study come from the Rural-Urban Migration in China and Indonesia (RUMiCI) project, which includes longitudinal surveys in both countries. The RUMiCI China survey comprises three randomly selected samples: $^{8}$ the rural household sample surveys households living in rural areas with rural Hukou (rural sample), the urban household sample covers households living in urban areas with Urban Hukou (urban sample), and the migrant sample comprises households working in urban areas with rural Hukou (migrant sample). The first wave of the survey was conducted in 2008. In 2009 a purposely designed module was added to help study selfemployment and credit constraints. In this study we employ the 2009 survey data from the urban and migrant samples. We restrict our sample to individuals who are aged 16 to 65 and at the time of the survey earn positive earnings from self-employment or wage-salaried jobs. ${ }^{9}$

The urban and migrant surveys were conducted in 15 cities from nine provinces: Guangzhou, Dongguan, Shenzhen, Zhengzhou, Luoyang, Hefei, Bangbu, Chongqing, Shanghai, Nanjing, Wuxi, Hangzhou, Ningbo, Wuhan, and Chengdu. ${ }^{10}$ The 2009 migrant sample has 5241 households and 8939 individuals. Of these individuals 7116 indicated that they were working at the time of survey. The urban sample in the same 15 cities has 4923 households and 14924 individuals. Among them, 6955 were working. Excluding observations with missing values, our final sample comprises 6789 migrant workers and 6487 urban workers.

One major concern arising from studies in other countries is whether the self-employment sector is where the bottom of society ends up, for instance as street vendors, house maids, gardeners, etc. If this is the case, self-employment may be regarded as a stepping stone to the formal sector and credit constraints are not a relevant consideration (Hamilton 2000; Blanchflower 2004).

To screen out those individuals for whom stepping-stone activities might be relevant, we define the current entrepreneurs as a sub-set of the selfemployed using the questions "Why did you become self-employed?" and "Do

\footnotetext{
${ }^{8}$ For detailed sampling information, see http: $\backslash \backslash$ rumici.anu.edu.au.

${ }^{9} 32$ migrants and 21 urban workers with zero or negative earned income are excluded. Inclusion of these observations does not change our results in any way. Unpaid family workers are excluded from the sample.

${ }^{10}$ The urban sample includes four other cities where no migrants were interviewed. These are excluded from the current study.
} 
you still want to become a wage-salary worker?". ${ }^{11}$ The group that indicates that their reason for becoming self-employed in the first place was that they were unable to find a wage-salary job and the group that indicated that they were currently still wanting to find a wage-salaried job, are labeled as a separate group of "involuntary self-employed".

Previous studies of other countries have looked at the general question of whether individuals want to be self-employed and suspicion has arisen that many individuals who say they want to be entrepreneurs are not serious. For example, when considering self-employment surveys in the OECD countries, Blanchflower (2004) notes the large discrepancy between the high proportions of employees who say they would like to set up their own business and the few who end up doing so.

Mindful of the possibility of cheap talk, we define a group of "want-to-be" entrepreneurs from the questions "Have you ever thought about becoming selfemployed?" with answers being: 1 . No, never; 2 . have not thought carefully as it seems to be too difficult, and 3. yes, I have thought (carefully) about it; and "If you have thought (carefully) about it, what stopped you from becoming one?". The choices for the second question are: 1. cannot borrow enough money; 2. do not have a network for obtaining a permit and/or customers; 3. A self-employed job is too hard; 4. The income for self-employment is too low; and 5. other.

We define "want-to-be" entrepreneurs to be those who indicated that they had thought (carefully) about becoming self-employed and that the reason they did not was either being credit constrained or network constrained. We interpret any other answer to the second question as not serious. We also asked all those who had thought about becoming self-employed what they thought they would need as an initial investment to set up the business of their own choice and the proportion of this initial investment that they could borrow from formal and informal financial institutions, relatives, and friends.

\subsection{General summary statistics}

Summary statistics are reported in Table 1, where the panels A and B present the information for the migrant and urban samples, respectively. The first rows of the two panels present the distribution of the workers among the four groups: the entrepreneurs, the involuntary self-employed, the "want-tobe" entrepreneurs, and the "happy to be" wage-salary earners. Of the 2061 migrant individuals who seriously thought about becoming self-employed,

\footnotetext{
${ }^{11}$ The precise questions are listed in Appendix A. The variable definitions closely mirror the survey by Qian et al. (2006).
} 
$76 \%$ reported they were either credit constrained or network constrained. They are termed "want-to-be" entrepreneurs. The salaried workers who do not profess a constraint-lead desire to be self-employed are included in the group that is happy being wage-salary earners. Among the 363 urban workers who seriously thought about becoming self-employed, those qualifying as "want-to-be" entrepreneurs account for only $38 \% .^{12}$

The table shows that around $28 \%$ of the total migrant workers are currently self-employed and $23 \%$ is defined in this paper as being entrepreneurs. Of the $72 \%$ of migrants who are currently wage-salary earners around onethird (or $22 \%$ of the total migrants) are "want-to-be" entrepreneurs and the rest are happy to be wage-salary earners. For the urban sample, selfemployment only accounted for $8.8 \%$ of the total workers and among them most ( 8 percent of the sample) are defined as entrepreneurs. Only $3.4 \%$ of urban workers are want-to-be entrepreneurs. These comparisons indicate that migrants are three times more likely to be entrepreneurs and 6 times more likely to be "want-to-be" entrepreneurs.

Table 1 also shows that among migrants, entrepreneurs work around 35\% more hours and earn $50 \%$ higher earnings than wage-salary workers. ${ }^{13}$ Among urban workers, entrepreneurs work $34 \%$ more hours and earn $23 \%$ higher earnings than wage-salary workers. These raw figures suggest that migrant entrepreneurs are relatively better-off than their urban counterparts. Another interesting point regarding hourly earnings is that the involuntarily self-employed not only on average earn less than the entrepreneurs but also earn less than the current wage-salary earners. This is true for both migrant and urban samples, suggesting that they are a very different group to the other self-employed. Indeed, if we compare this group with that of the entrepreneurs, we find that they are older and less educated.

Other information presented in Table 1 shows that migrant and urban entrepreneurs, as well as involuntarily self-employed, are older than wagesalary earners, and that they have less schooling. Given the strong increase in education in recent years (Luo et al. 2010), the lower education of the entrepreneurs is partially directly due to their older age. In addition, for the

\footnotetext{
${ }^{12}$ As a comparison, Qian et al. (2006) found that 48 out of their 82 interviewees who were 'serious' about becoming self-employed listed credit constraints and network constraints.

${ }^{13}$ Since total income equals revenue minus costs, there is more scope for the self-reported total income of entrepreneurs to be biased. We tried to cross-validate the income data with total household consumption data. The ratio of consumption to income is $67 \%$ for entrepreneurs versus $63 \%$ for salaried workers, indicating that if the unobserved savings ratios are the same for both, total income is actually relatively underestimated for entrepreneurs. The raw-difference in consumption expenditure between entrepreneurs and salaried migrants is thus almost exactly the same as that of total income (50\%).
} 
migrant sample we find that the self-employed have been in cities longer and are more likely to be women. With regard to industry distribution, the selfemployed are more likely to be in retail/wholesale trade and service sectors, while higher percentages of wage-salary earners are working in construction, manufacturing and other sectors. These patterns are consistent across the two samples.

\subsection{Trust, risk-taking, networks, and financial shocks}

Given the importance of risk-taking in the literature on entrepreneurs, the survey asked individuals to assess their own risk taking tendency. The question we used was "Some people in a society are more likely to take risk while others are less likely. On a scale from zero to ten, where zero indicates 'do not take any risk' and ten indicates 'like to take risk very much', could you please rank your own risk taking level". We also assessed individuals' trust behavior by asking them to answer the following question "In general, do you think most people can be trusted?" and the answers are 1. yes, most people can be trusted; 2. one should be careful about other people; and 3. do not know.

Entrepreneurs are generally thought to be more risk-taking and this has previously been found in China too (Qian et al. 2006). Table 1 shows that the "want-to-be" entrepreneurs in both samples seem to have the highest average risk scores, while the self-employed (both entrepreneurs and involuntary selfemployed) in the migrant sample are in the least risk taking group. This is rather counter intuitive. But as these are unconditional means, it is likely that the low scores for the self-employed group is related to the fact that on average they are much older than the salaried workers and that age is often found to be positively correlated with risk aversion in the literature. For the urban sample, it is the wage-salary earning and prefer-to-be wage-salary earners group which has the lowest risk score, more in line with expectations and the earlier findings of Qian et al. (2006) whose sample consisted of Urban Hukou holders.

Table 1 also reports the proportion of respondents who thought that most people can be trusted. It seems that the self-employed (both entrepreneurs and involuntary self-employed) have the lowest trust score in the migrant group, while the "want-to-be" entrepreneurs have the highest scores. For the urban workers, current and "want-to-be" entrepreneurs have similar scores on trust, again a finding that mimics the results of Qian et al. (2006) where $56 \%$ of urban entrepreneurs thought most people could be trusted, compared to $54 \%$ of their urban salary workers. Hence there certainly seems to be a selection on trust and risk amongst entrepreneurs but not in the direction 
initially expected and clearly differing by sample.

Our survey also asks individuals to report on how many people they contacted during the last Chinese New Year by sending cards or exchanging presents, and among them how many were located in urban areas. The information on total contacts can be used as a proxy for the size of the network of an individual. The summary statistics show that on average urban workers have more contacts than migrant workers. In addition, "want-to-be" entrepreneurs have larger networks than others in both samples. However, the quality of the network defined this way may differ considerably between migrants and urban local workers in that migrant contacts includes people living in their hometown rather than in the city they currently live in. Because it is the urban contacts which capture the social capital better, in the main regression below we use the total number of contacts which are from the city individuals are currently living in. The data presented in Table 1 shows that while only $45 \%$ of the migrant contacts are living in the same city, this ratio for urban workers is $88 \%$.

Finally, all the respondents in our survey were asked to report whether in the past year $(t-1)$ a series of life events happened to them or their family members. The nine events included: 1 . A marriage; 2. Found a partner; 3. A pregnancy; 4. A birth of own children; 5. Found a good job; 6 . A divorce or separation; 7. Serious illness or injury; 8. A death in the family; 9. Built or bought a new house. Among these events, the last four (6 to 9 ) should be significantly related to credit constraints as they inevitably require significant amounts of spending at the household level. We therefore construct a dummy variable indicating whether any of these four events occurred during the past year. Among migrants, those in the involuntary self-employment and the "want-to-be" entrepreneur group have the highest probability of having any of the above mentioned events occur during the past year; whereas among urban workers, the events seem to have occurred equally across the four groups of individuals.

\subsection{Laboratory experiments}

Table $1 \mathrm{~b}$ shows the summary statistics for the sub-sample of 1633 migrants who were involved in laboratory experiments. These experiments were done in rented school classes, with participants being given a show-up fee and compensated for their travel costs. The amount the participants earned hourly on average corresponded to more than double their normal hourly earnings (i.e. they were given about some 20 Yuan per hour). Although a random sample of the surveyed migrants was invited to participate, Table $1 \mathrm{~b}$ shows that the people who turned up were not representative of the migrant 
survey population. There are fewer entrepreneurs (15\% as opposed to $23 \%$ ), they are younger (30.53 years on average as opposed to 31.92$)$, they are much more risk-taking (their self-assessed risk score is 4.24 as opposed to 3.34), and they essentially vary in most dimensions from the general migrant sample. This in itself shows the difficulty of getting a representative sample of people to participate in field experiments.

The experiments consisted of an IQ test that took about 30 minutes, a risk-taking game that consisted of individuals picking a switching point corresponding to a particular lottery with an ever increasing probability of winning but a lower gain if successful (the higher the switching point, the more risk-averse an individual), and a pure reciprocity game where individuals were paired and one sent the other a certain amount of money which got multiplied by three after which the person who was sent the initial amount had the option of sending back a discretionary amount. The amount originally sent is taken as a measure of the degree of trust of the sender, and each participant had a turn at being the sender. Further details of the experiments are presented in Appendix B

One question that can immediately be answered with these laboratory tests is how well they line up against subjective measures of risk and trust. Dohmen et al. (2005) and Ding et al. (2010) find that questionnaire responses to the general risk question are reliable predictors of actual risk-taking behavior in experiments. For our sample, Figure 1 presents the relation between self-assessed risk and trust measures and the risk and trust measures revealed from the game data. The left panel shows the relation between the real lottery game switch point, where a higher switch point means the subject is more risk averse, and our self assessed risk measure which is increasing in the level of risk-loving. The graph shows a strong relation, with a correlation coefficient of 0.70 . The right panel presents the relation between self-assessed trust and the trust game result. The fitted line again shows a strong relation with a correlation of 0.56 , meaning that self-reported measures of trust and risk-taking do seem to be reasonably good measures of how individuals behave in actual choice experiments.

\section{$5 \quad$ The earnings of entrepreneurs}

In this section we look at the wage premium for being an entrepreneur and the extent to which the high premium is due to barriers to entry.

Tables $2 \mathrm{a}$ and $2 \mathrm{~b}$ show the results of standard hourly earnings regressions. The "earnings" for self-employed individuals are measured as net revenue (total revenue net all the input costs as judged by respondents) 
divided by hours worked. Table 2 a reports the results for regressions on absolute earnings while Table $2 \mathrm{~b}$ reports the results for log-earnings. Analyses for log-earnings are more standard in the literature as they have appealing rates-of-returns interpretations if that there is no heteroskedasticity. However, it is well-known that entrepreneurs have much more volatile earnings than salary-earners (Portes and Zhou 1996; Hamilton, 2000) meaning that regressions on log-earnings will seriously under-estimate the actual aggregate differences in earnings. Thus, the discussion below will focus mainly on Table 2a.

The baseline model includes the following covariates: age and its squared term, years of schooling, gender and marriage dummy variables, and controls for city and industry of employment. In addition, we include dummy variables for entrepreneurs, for migrants, and for the interaction of entrepreneurs and migrants. This interaction term is essentially a difference-in-differences measure of the relative gain migrant entrepreneurs make relative to urban entrepreneurs.

In both tables, the control variables have the right signs and reasonable magnitudes. Standardizing for city and industry of employment, there is an inverse U-shaped age-earnings profile for all the samples. Returns to years of schooling ranges between 5 to $7 \%$ depending on which sample is used. Men earn around 15 to $24 \%$ more than women, and urban workers have a positive marriage premium.

Turning to the variables of main interest, Table 2a confirms many of the suppositions of the institutional section and the descriptive model. For one, migrants earn much less than their comparable urban counterparts. The first column of the Panel A shows that migrants, after controlling for education, region, industry, and basic demographics (gender, age, marriage), earn 5.66 less yuan per hour, which is about $75 \%$ of the average migrant hourly wage and $34 \%$ of the average urban hourly wage, meaning that the comparable urban resident earns nearly twice as much. The log-earnings regressions in Table $2 \mathrm{~b}$ tell the same story with migrants earning $41 \%$ less than their comparable urban counterparts.

Column 2 of Table 2a shows that migrant entrepreneurs earn about 1.99 yuan more per hour than comparable salary earners, which amounts to about $26 \%$ of average migrant hourly earnings and is highly significant. The comparable estimate for urban residents in the third column 1.84 yuan per hour which is about $11 \%$ of average urban hourly earnings and turns out to be insignificant. In the logarithmic regressions of Table $2 \mathrm{~b}$, which ignore the difference in log-variance, migrant entrepreneurs earn $5 \%$ more than their salaried counterparts (column 2), showing the importance of taking account of the differential variability of earnings in the entrepreneurial sector. We can 
mention that it makes little difference for the effects of being an entrepreneur if we also allow for sector-specific effects of experience (Hamilton 2000), but because tenure is quite strongly correlated with age and education we do not include it in the main regressions.

\subsection{Is the high premium for entrepreneurs due to re- turns to their investment?}

One might argue that the high return to entrepreneurs is mainly due to the fact that the net revenue used to measure entrepreneur earnings has a return to capital investment component. Fortunately our data allow us to directly test the degree to which entrepreneurs make excess returns on their investments. To gauge the presence of excess returns, we estimate the basic models again, including the real initial investment ${ }^{14}$ for all the self-employed. The value of initial investment for wage-salary earners is set to zero and the results are reported in Panel $\mathrm{B}$ of Tables $2 \mathrm{a}$ and $2 \mathrm{~b}$.

Including real initial investments for the self-employed does not change the results for any other control variables, meaning that it is not the case that the initial returns to entrepreneurship were due to an overstatement in the net revenue: the separate regression for the migrant sample shows that taking initial investments into account reduces the return to entrepreneurs from 1.99 yuan per hour to 1.69 yuan per hour, which is still $22 \%$ of average migrant earnings. For the urban sample, the original insignificant effect remains insignificant once the initial investment is included.

The return to initial investment is much higher for the migrant sample than for the urban sample. For every additional 100,000 Yuan initial investment, a migrant earns 1.2 Yuan per hour more. Given that the average migrant entrepreneur works about 3900 hours per year $\left(=75^{*} 52\right)$, this makes the excess return $4.7 \%$ per year. The equivalent point-estimate for the excess return made by urban entrepreneurs is an insignificant $0.76 \%$. The substantial difference in excess returns to investment between migrant and urban local entrepreneurs is an important indication that migrant entrepreneurs faced stronger credit constraints than the urban entrepreneurs.

\footnotetext{
${ }^{14}$ The initial investment is deflated on a series of provincial level CPI with 1995 set to 100. In terms of interpretation, we here think of start-up capital as both a human capital variable with a return and as a threshold of credit an entrepreneur needs to get started (i.e. it is taken to be exogenous but with a return).
} 


\subsection{Is selectivity important?}

A key source of doubt about the found 20-30\% earnings differential between migrant entrepreneurs and salary earners is the potential selection of entrepreneurs on unobservables. The first check on the importance of 'unobservables' is presented in panel $\mathrm{C}$ of Tables $2 \mathrm{a}$ and $2 \mathrm{~b}$. There, we include self-reported measures of trust, risk-taking, and social networks intended to control for individual traits important in the value of being an entrepreneur. As these traits are not controlled for in normal earnings equation estimations, we regard them as part of the 'unobservables'. As shown in Tables $2 \mathrm{a}$ and $2 \mathrm{~b}$, inclusion of these 'unobservables' hardly changed the estimate of the earnings benefit of being an entrepreneur: from 1.69 Yuan per hour in the second column of panel B to 1.66 Yuan per hour in the third column of panel C. None of the other coefficients change much either, though it can be noted that risk-taking itself has a positive effect on earnings at borderline significance levels for migrants.

A second check on the importance of unobservables is to use the part of the sample that is followed over time and to see what the wage increase is for those who switched from wage-salaried workers to entrepreneurs over the two years. Due to the very high mobility in the panel and the general fear of the migrants about being monitored, we have information on only $40 \%$ of the sample for both 2008 and 2009. Controlling for individual fixed effects we find that those who changed from wage-salary earners in 2008 to self-employed in 2009 on average gained 10 percent in hourly earnings. ${ }^{15}$ Given the high probability of selectivity bias due to the high attrition rate for the longitudinal survey and the fact that most of the entrepreneur-related variables are only available for 2009 and hence cannot be controlled for in the fixed effect estimation, we see these results more as confirmatory than central.

Another check on selectivity is to ask the migrant entrepreneurs how much they expect to earn as salaried workers. Presuming that entrepreneurs know about their own productive characteristics, their answers should be informative about whether there is something unobserved that makes them more productive in general or whether their own estimate of the earnings benefit of being an entrepreneur coincides with that of the cross-sectional differences. We compare the self-reported hypothetical earnings with the actual earnings made by entrepreneurs (see in the first and second rows for the entrepreneurs and involuntary self-employed columns). The table shows that on average entrepreneurs currently earn 8.36 Yuan per hour whereas they expect to earn only 5.63 Yuan per hour if they were a salaried worker,

\footnotetext{
${ }^{15}$ These results are available upon request from the authors.
} 
around $33 \%$ lower than the amount they currently report to make. This counterfactual earnings differential is even larger than what we observed from the cross-section data comparison, suggesting that unobserved heterogeneity in earnings potential is not a likely cause of the observed difference in earnings between entrepreneurs and wage-salary earners.

Another check is to allow for differential returns by estimating wage regressions for entrepreneurs and wage-salary earners separately (reported in Appendix C) and use the estimated coefficients for wage-salary earners and entrepreneurs to predict what would have been the earnings for entrepreneurs and wage-salary earners had they been employed in the alternative sectors, respectively. ${ }^{16}$ These comparisons are reported in rows 3 and 4 of Table 3a.

We find that the amount entrepreneurs are predicted to earn in the salary sector using regression estimates is $22 \%$ less than what they are currently earning. The average "happy to be" wage-salary earners would have earned $30 \%$ higher earnings as entrepreneurs while the want-to-be entrepreneurs would have earned $40 \%$ higher earnings according to our regression estimates. These results all echo the results of Table 2, in that no differential rate of return in observables takes away the basic finding of no less than $22 \%$ earnings premium for becoming an entrepreneur. ${ }^{17}$

Our last check on the importance of 'unobservable' characteristics relies on the laboratory tests to ascertain subjects' IQ scores, their level of trust, and their risk-taking. Earnings regressions taking those normally unobserved characteristics into account for the sub-sample of laboratory participants are reported in Table 3b. There are two noteworthy items about these results. The first is that none of the laboratory assessed measures (including risk) are actually significant determinants of earnings, although they all have the right signs. This is obviously unexpected and not in line with studies for other countries (Blanchflower, 2004). One explanation is that individuals who participated in the experiment are a selected group of more risk loving and trusting people. As a check on the selectivity, we replicated panel $\mathrm{C}$ of Table $2 \mathrm{~b}$ for the experimental sample (not shown), i.e. used their self-reported

\footnotetext{
${ }^{16}$ We run these separate regressions to allow for the possibility that the rates of return to certain variables is very different across the two groups and that hence some individuals might have a comparative productivity advantage in one group or the other. As shown in Appendix C, the rate of return to education is much lower for the self-employed group, while the returns to risk taking and social networks are much higher. The main group for which this matters in terms of counterfactuals turns out to be the involuntary selfemployed group.

${ }^{17}$ Confirming the strong selectivity of those who do not want to be entrepreneurs, the involuntary self-employed are predicted to earn slightly more in the wage-salary sector partially because of their lack of social networks which are worth a lot as entrepreneurs but not much as salary earners.
} 
measures rather than the measures derived from their choice behaviour. It turned out that the effects of self-assessed risk and trust measures were significantly different between the general migrant sample and the experimental group, confirming a selectivity on important unobservables.

The second salient aspect of Table $3 \mathrm{~b}$ is that the estimates of the effect of becoming an entrepreneur on earnings is near identical to those of Table 2a. An entrepreneur is estimated in column 1 to earn 1.91 yuan more than a salaried individual, dropping to 1.79 yuan when account is taken of IQ, risk-taking, and trust (column 3). Indeed, the estimated effect on log-wages in columns 4 to 6 is higher than the previous estimates of Table 2b. Since the sample for Table 2 was designed to be representative of the migrant population whilst the laboratory sample is not quite as representative, we prefer the estimates of Tables 2, but note that, if anything, the laboratory sample gives even higher estimates of the earnings benefit of being an entrepreneur.

The above analysis suggests that although individual heterogeneity may contribute to some of the observed high returns to entrepreneurs, the large bulk of those returns cannot be explained by it.

\section{The impact of credit constraints on entre- preneurial choice}

If being an entrepreneur brings significant payoffs to migrants, then, what does it take to become an entrepreneur? In this section we examine what differentiates a current entrepreneur from an average wage-salary earner, a happy-to-be wage-salary earner, and a "want-to-be" entrepreneur. Given that migrants have a much higher proportion of current and "want-to-be" entrepreneurs, the analysis below focuses on the migrant sample.

Echoing the methodology of Blanchflower and Oswald (1998) and the subsequent literature that has tried to use random fluctuations in wealth to see if credit constraints matter (Hurst and Lusardi, 2004; and Nanda 2010), we will use negative financial events in the previous year to help predict who is an entrepreneur. The "credit constraining" events in question (marriage break-downs, illness and death in the family, and building or buying houses) should have a significant impact on individuals' current liquidity as all these events put strains on the finances of the household and therefore should make the credit constraint more binding, whilst they should have no direct effect on the innate benefits of becoming an entrepreneur. We test the sensitivity and validity of using these negative events as a proxy for negative financial shocks. 
We estimate probit as well as multinomial logit models to examine the question of what it takes to become an entrepreneur, but given the high degree of similarity of the results only report the results from the probit models.

\subsection{Comparing entrepreneurs to average wage-salary earners}

We report in column 1 of Panel A of Table 4 the marginal effects from a probit model of currently being an entrepreneur versus being a wage-salary earner (including want-to-be entrepreneurs and happy-to-be wage-salary workers) for the migrant sample.

The results show that both age and 'year since migration' contribute significantly to whether an individual is self-employed or not, with the older and more established migrants more likely to be entrepreneurs. In addition, married people, less educated people, and females are more likely to be an entrepreneur. Each additional year of schooling increases an individual's probability to be a wage-salary earner by 1.7 percentage points, which reflects the finding of Appendix $\mathrm{C}$ that the relative payoff to education is higher in the salaried sector than the entrepreneurial sector. The self assessed risk score does not significantly predict who is an entrepreneur and who is a wage-salary earner, though we do observe a positive sign. Both a greater degree of trust and a larger network increase the probability of being an entrepreneur. Someone with no network is nearly $15 \%$ less likely to be an entrepreneur than someone with an average size network (25 contacts), i.e. $25^{*} 0.006$. Someone who believes others can be trusted is $3.9 \%$ less likely to be an entrepreneur.

The value of the house in the home town contributes significantly positively to the probability of being an entrepreneur. Every additional 100,000 yuan increase in hometown housing value is associated with a 2 percentage point increase in the probability of being an entrepreneur. Given that 100,000 yuan corresponds to the 90th percentile of housing values in the hometown, and the medium value is only 20,000 yuan, this shows that housing wealth in the countryside has but little effect on who is an entrepreneur for the majority of the sample. ${ }^{18}$

\footnotetext{
${ }^{18}$ In fact, our results fit in with Hurst and Lusardi's (2004) and Nanda's (2010) finding that the impact of wealth on the probability to be an entrepreneur is quite non-linear, in that housing values are highly skewed. We may mention that the functional form of the effect of housing values does not matter, in that including higher order polynomial terms does not change the other effects.
} 
The most interesting finding here is that the credit constraining events have a significant negative effect on the probability of entrepreneurship. On average, an individual having had any of the four events occur in the past year is $3.1 \%$ less likely to be an entrepreneur this year. This is a considerable effect taking into account that the average proportion of current entrepreneurs is just $23 \%$ of the total migrant workforce.

\subsection{Comparing entrepreneurs to happy-to-be wage-salary earners}

Column 2 of Panel A compares the current entrepreneurs to the "happyto-be" wage-salary earners, hence excluding the "want-to-be" entrepreneurs from the group of salaried workers to see if the results of column 1 are contaminated by the presence of credit constrained individuals in the group of salaried workers.

By and large, the differences between column 1 and 2 of Panel A are small. There are no sign reversals and most of the effects that were significant stayed significant. Two exceptions are worth mentioning. The first is that the effect of gender has virtually disappeared: whereas men were $2 \%$ less likely to be entrepreneurs and hence $2 \%$ more likely to be salary earners in column 1 (Panel A), men are only $0.7 \%$ less likely to be entrepreneurs than "happy-tobe" salary earners. This indicates that the excluded group of "want-to-be" entrepreneurs is disproportionately male. The other exception is that the credit constraining events are no longer significant, which is what one would expect because we have now excluded the group that have been prevented from becoming an entrepreneur due to the negative financial shocks.

\subsection{The want-to-be entrepreneurs}

The final two columns (columns 3 and 4) in Panel A compare the observed characteristics of "want-to-be" entrepreneurs with current entrepreneurs (column 3); and with their happy-to-be wage-salary earning counterparts (column 4 of Panel A).

The results from column 3 in Panel A show that an extra year of education makes a person $2.5 \%$ more likely to be a "want-to-be" entrepreneur rather than an actual entrepreneur. As expected from the previous column, males are much more likely to be "want-to-be" entrepreneurs than entrepreneurs. Interestingly, self-assessed risk-taking has no independent effect, showing that the aggregate differences in risk-taking between these groups found in Table 1 is indeed mainly a function of the other sources of selection (age, gender, and initial wealth). 
Most importantly, our "want-to-be" group seems to be much more credit constrained: a credit constraining event makes it $10.6 \%$ more likely to be a "want-to-be" entrepreneur than a current entrepreneur. In addition, the value of the hometown house has a greater effect on the probability of being an entrepreneur than any other comparison group, consistent with the idea that credit constraints are relatively important for this group.

Thus, with regard to the characteristics which were commonly found to be important in becoming an entrepreneur, we find that the "want-to-be" entrepreneurs are equally risk loving, have an equally large social network in the city they lived in, and are more educated. The most important difference is that the want-to-be entrepreneurs are more likely to have suffered from a credit constraining event than the entrepreneurs.

Column 4 of Panel A is in a sense the mirror image of the previous columns. The most important finding is that "want-to-be" entrepreneurs are more likely to have had credit constraining events than happy-to-be salary earners. As a causal factor this would make little sense (why would an illness in the family make you more likely to want to be an entrepreneur?), but it makes immediate sense if it were true that those who did not suffer from such an event were more likely to have already become entrepreneurs.

\subsection{Sensitivity tests for credit-constraining events}

There are important endogeneity concerns with the analysis above. Our first worry is that some of the events used may not be very random. For example, building or buying a house in the hometown and having a marriage breakdown are to some extent forward-looking choices that may reflect anticipated stable future income streams. Also, one can argue that one should not use a dummy of whether any of the four events happened but rather a cumulative index.

To test whether our results so far hinge on the way we measure the creditconstraining events, we construct five alternative measures and report the results in Table 5. The first measure uses all four events listed above but instead of using a dummy variable for the presence of at least one event, we use the number of the events that occurred (row 1 of Table 5). The second and third measures exclude "built or bought a new house at hometown" from the measure and uses both "any event" dummy (row 2) and number of events (row 3); whereas the fourth and fifth measures further exclude "divorced or separated in the past year" and again measures it using the dummy (row 4) and number of events (row 5).

We can focus still more precisely on those life events that are a random shock to wealth by using additional information in the survey on whether 
the events were expected or not. When we count only those events that are self-reported as being unexpected, we get the results in rows 6 to 8 of Table 5. When we count only unexpected events, the effects of the life events becomes stronger than before. For example, with the 'any of the two events' measure (row 4), those who experienced the events are 10 percent less likely to become entrepreneurs, while using only the unexpected events increases the effect to 15 percent (row 8).

Finally we use as additional controls the number of months in continuous employment (in order to allow for interruptions to work) in the current city for the last year and current mental health (in order to allow for reverse causality), which is derived from the 12-item General Health Questionnaire (GHQ). Following the standard approach in the literature we sum the 12 GHQ responses (GHQ12) to form an index ranging from 0 to 36 (called the Likert scale), with 0 representing the highest level of mental health and 36 representing the lowest level. ${ }^{19}$ The results presented in row 9 of Table 5 show that including these two additional variables makes little difference to the estimated impact of life-events.

The results shown in Table 5 provide a very consistent pattern in that having the events occur in the past year has no significant effect on whether an individual is more likely to be an entrepreneur or not for the happy-to-be wage-salary earners, no matter how the events are measured. Yet, the creditconstraining events always make it less likely to be an entrepreneur for the want-to-be entrepreneur group, no matter how we measure the events. In fact, the effect becomes stronger when only the most random events (serious illness in the family and death in the family) are included and individuals' current mental health status and the length of continuous employment in the cities are controlled for.

\section{Credit constraints and welfare implications}

In this section we investigate the extent to which "want-to-be" entrepreneurs are credit constrained, and the welfare implications of the credit constraints. In the survey we explicitly ask the "want-to-be" entrepreneurs the initial investment required for the type of business they wish to establish and how much they think they could borrow for the initial investment from formal and informal financial institutions, and relatives and friends. For the current

\footnotetext{
${ }^{19}$ The GHQ12 is commonly used by medical researchers, epidemiologists, and economists as a measure of psychological distress (see Blanchflower and Oswald, 2008; Jones and Wildman, 2008; and Madden, 2009 for recent economics applications). The detailed questions of the GHQ12 asked in the RUMiCI survey are presented in Appendix A.
} 
entrepreneurs we also inquired into their level of initial investment and the total amount borrowed from formal and informal channels.

\subsection{Levels of credit constraints}

The first row of Table 6 presents the average total amount of the anticipated investment required for the "want-to-be" entrepreneurs and the actual initial investment for the current entrepreneurs. The initial investment of the current entrepreneurs have been adjusted for the cumulative inflation since the starting year so that they are comparable with current anticipated investment, but given the consistent $10 \%$ economic growth in China in the last few decades it would be reasonable to expect the amount of initial investment needed to have grown faster than inflation.

The first column in Table 6 shows that on average the level of investment the want-to-be entrepreneurs report to need is around 1.6 times higher than the average amount the current entrepreneurs actually invested at the start of their business. One reason for this discrepancy is the gradual increase in investments and the fact that we are comparing current want-to-be entrepreneurs with all the current entrepreneurs, a large number of whom started their business many years ago. If we instead look at the 68 individuals who started their business in 2009, the average level of initial investment is 50,425 yuan, which is only slightly higher than the medium value of the "want-tobe" entrepreneur group's anticipated initial investment but still nearly three times the average migrant yearly income. The remaining discrepancy concurs with prediction 4 of our initial model, which is that those migrants who become entrepreneurs are more likely to have had relatively modest needs in terms of starting capital.

Figure 2 presents the distribution of the anticipated and actual investment for the two groups, which shows that the mean value difference is not driven by extreme values, though the distributions do look quite different. Whereas the actual investments are more continuously distributed around their mean, the distribution of anticipated investment is lumpy with particular peaks just around 50,000 yuan (or 10.81 log points), which is the medium value, and again around 100,000 yuan (11.51 log points), which is the $75^{t h}$ percentile in the distribution. The anticipated investment has a markedly lower variance. The reason that the distribution of the actual initial investment is more variable than the anticipated initial investment may be because the former occurred over more years but it seems likely that there is some degree of anticipation error involved too. The top left panel of Figure 3 shows the locally weighted regression plot of the evolution of actual initial investments by year of the start of the business. The top left panel reveals that there is 
more than 100 percent increase in the level of initial investment since 1995.

The next four rows of Table 6 report the proportion of the investment (anticipated or actual) that was (or could be) borrowed from the formal and informal financial institutions and from relatives and friends.

On average, the current entrepreneurs borrowed a significantly lower proportion of their initial investment from all channels than their "want-to-be" counterparts anticipate being able to borrow. This could be due partially to the difference in timing of the investment. Over the past 10 to 15 years, financial markets in China have expanded and have started to lend to private firms and individuals (see, for example, Farrell and Lund, 2006). Similarly, as the economy grows, individuals become richer and have more collateral with which to get loans from relatives, friends, and institutions. Nevertheless, it may also indicate individuals' anticipation errors.

The top right panel of Figure 3 shows the percentage of the initial investment that was reportedly borrowed from formal financial institutions, increasing from no more than $1 \%$ in 1995 to still less than $5 \%$ in 2009 . The bottom left panel shows the proportion borrowed from informal channels, relatives and friends, which increased in the late 1990 from $7 \%$ to $13 \%$, but has since been on a slow decline to about $12 \%$ in 2009 . The final panel on the bottom left shows the total proportion of the initial investment that was borrowed, increasing from a low of $12 \%$ in 1995 to the current high of $23 \%$ in 2009. Hence the proportions that can be borrowed have indeed increased, though for all periods it is clear that the vast bulk of the initial investment was not financed by borrowing but from savings, a direct indication of the actual difficulties of borrowing money.

The summary finding of Table 6 is that on average, the currently want-tobe entrepreneurs believe that they can borrow $12 \%$ of their initial investment from the formal financial institutions and $31 \%$ from other sources, while our data on actual borrowing suggest they would only be able to borrow $5 \%$ from formal institutions and no more than $15 \%$ informally. Another way to put this is that the "want-to-be" entrepreneurs themselves think they need to come up with around $60 \%$ of their anticipated initial investment, whereas history would suggest they need $80 \%$. This is an average of 51,000 to 70,000 yuan from their own savings. If we consider that this group on average earns 19,776 yuan per year (see Table 1), the savings required for the initial investment is equivalent to 2.6 to 3.5 years of total earnings.

To further assess whether the required level of investment anticipated by the want-to-be entrepreneurs is reasonable, we ran regressions of the determinants of log anticipated/actual initial investment. ${ }^{20}$ The results are presented

\footnotetext{
${ }^{20}$ The additional control variables for the current entrepreneur group are a vector of
} 
in the first two columns of Table 7.

In Table 7, the determinants of log initial investments are very similar to that of $\log$ anticipated investments. The one clear exception to the general rule that whatever significantly affects actual investments also affects anticipated investments is the role of gender. Whilst males anticipate needing $19 \%$ higher initial investments than females, current male entrepreneurs report to have needed $7.5 \%$ less than female entrepreneurs. The most probable explanation is that men exaggerate, on average, how much investments they need, possibly hoping to impress the survey conductor

Otherwise, those who are more risk-loving expect to need and have actually needed higher initial investments; the more educated report to need and have needed higher initial investments; and those with more valuable hometown houses report to need and have needed higher initial investments.

One remaining question is whether the shortfall in the amount one can borrow is affected by whether there were credit-constraining events in the past year. To examine this issue, we estimate an equation on the level of the difference between investment required and the amount that is expected to be borrowed. The results of the OLS and Tobit model are reported in columns 3 and 4 of Table 7 , respectively. Controlling for all the individual characteristics included in other regressions and standardizing the initial investment required, we find that those with credit-constraining events have an additional gap of 5454 to 6290 yuan in their investment, depending on the estimation method used. This is about $10 \%$ of the total investment needed and seems to further confirm that the events we use are indeed credit constraining.

\subsection{Welfare implications}

The total amount of additional income that can be earned by migrants in the absence of credit constraints $\Delta W$ equals:

$$
\Delta W=\sum_{i \in S}\left[w_{i, e n}-w_{i, s a}\right]
$$

where $S=\{$ want-to-be entrepreneur $\}$. In order to calculate this number, we have to generate a counter-factual for $w_{i, e n}$. We can take three approaches to this, reflecting the different hourly return estimates:

1. A conservative assumption would be that the only difference between sectors is the earnings levels for non-Urban Hukou holders, whilst there

dummy variables indicating the year the business was first started, using 1995 and before as the omitted category. 
is no difference in the returns to any skill. We can then take the most conservative measure of wage differentials we have found in Table $2 \mathrm{~b}$ (1.656 yuan) as a guide for the production increase available to "wantto-be" entrepreneurs when they become actual entrepreneurs. The average"want-to-be" entrepreneur can expect a yearly income increase of around 6210 Yuan assuming that they would work 75 hours a week (same as the average hours worked by the current entrepreneurs, see Table $1 \mathrm{a})$ and 50 weeks a year $(=75$ hours $* 1.656$ yuan $* 50$ weeks). Table 8 shows that this equates to $28.4 \%$ of average migrant yearly earnings. Given that $22.7 \%$ of migrants are in the want-to-be entrepreneur category, this in turn equates to an average increase in migrant earnings of $6.5 \%$. If we then allow for the fact that migrants make up about one third of the urban labour force and that the average migrant earns $68 \%(=1822 / 2667)$ of an urban resident, then the $6.5 \%$ increase per migrant equates to a $2.1 \%$ increase in the total amount of earnings for all workers in the cities, which is about 1.0\% of GDP assuming that the share of labour in GDP is about $50 \%$ in China (which is close to the share found by Li, Liu, and Wang, 2009).

2. (some selection) Next, we can allow for differential rates of returns to skill and hence a greater degree of selectivity of the want-to-beentrepreneurs. We thus take $\widehat{w_{i, e n}}-w_{i, s a}=x_{i}^{\prime} \beta_{e n}-x_{i}^{\prime} \beta_{s a}$ from the separate earnings regressions for entrepreneurs and want-to-be entrepreneurs in Appendix A. In that case, the average income-increase is 4.29 Yuan per hour, translating to a $16.7 \%$ increase in migrant wages, which is a $5.6 \%$ increase in total urban earnings, and roughly $2.8 \%$ of GDP.

3. (structural) Finally, we can allow for both differential rates of return and individual unobserved heterogeneity by using the prediction of the want-to-be entrepreneurs themselves. Under rational expectations, this should be free of any systematic bias or error in modelling approach. From Table 3a we know that the average expected self-reported hourly earnings increase is 3.01 Yuan (=10.34-7.33), which translates to a $3.9 \%$ increase in total urban earnings and roughly $2 \%$ of GDP.

The benefits of overcoming credit constraints are thus found to be $1 \%$ to $2.8 \%$ of GDP. The true effect could be higher due to spill-overs of entrepreneurial activities and lower due to general equilibrium effects. Positive spill-overs that relate entrepreneurship to general development have often been argued to exist (Banerjee and Newman 1993). Glaeser (2007) for instance found that a high density of entrepreneurs in the U.S. is related to the 
subsequent growth of the urban economy, whilst for the whole of the OECD entrepreneurial density has been related to positive knowledge spill-overs and higher growth-rates of whole economies (Praag and Versloot, 2007).

Alternatively, if we reflect on the likely general equilibrium effects of having a large additional influx of self-employed people as well as a large reduction in the number of salaried workers, we should expect a reduction in the wage premium of being self-employed and an increase in the wages of the salaried workers. Under any constant-returns to scale societal production function, the net effect of these changes will be less than the partial increase in wages of the affected group. ${ }^{21}$

\subsection{Does more discrimination beget more potential en- trepreneurs?}

A direct prediction from our simple model was that the higher the relative degree of discrimination, the more individuals would want to become entrepreneurs. Particularly if there are positive spillover effects of entrepreneurs, this mechanism can lead to a perverse positive effect of outright discrimination of a particular group (migrants). In order to explore this further, we use the fact that we have 15 cities in our sample that differ with respect to how they treat migrants. In some cities, migrants are more restricted in which jobs they can undertake in the formal sector than in other cities. In order to see if discrimination is truly a push-factor, we estimate wage-regressions that allow for a different effect of Urban Hukou in the salaried sector for each city. The coefficients on the migrant dummy variable (which we will take as the measure of discrimination) for each city are presented in the first two columns of Panel A in Table 9, whereas the proportion of the salaried migrant workforce who are want-to-be entrepreneurs and the proportion of total migrants who are either entrepreneurs or want-to-be entrepreneurs are listed in columns 3 and 4 of the Panel A.

Panel B of Table 9 presents two regression results. The first row of this panel shows the effect of differential treatment on the proportion of migrant salary workers who want to be entrepreneurs. The result shows that a $1 \%$ in-

\footnotetext{
${ }^{21}$ The precise assumptions on the nature of the discrimination also matter. If we interpret the discrimination as an avoidable loss of productivity due to entry barriers into the more productive jobs within the salaried sector, then overcoming the discrimination via the competitive pressures of free-entry into the entrepreneurial sector would itself be worth about $3 \%$ of GDP (the $40 \%$ wage differential times the $77 \%$ of non-entrepreneurs). If, on the other hand, the discrimination takes the form of pure rents that are monopolised by the urban workers, there is no additional production benefit from dismantling discrimination.
} 
crease in the gap between the earnings of migrants and Urban Hukou holders in the salaried sector increases the proportion of wage-earning migrants that wants to be entrepreneurs by $0.4 \%$ (significant at the 0.01 level). The second row shows that the combined proportion of entrepreneurs and want-to-be entrepreneurs goes up by $0.22 \%$ with every $1 \%$ increase in the unexplained earnings gap between migrants and urban workers, though this is only borderline significant. Although somewhat tentative, these results do suggest that discrimination is a push-factor for migrants. It would then be the case that a complete removal of discriminatory treatment between migrants and Urban Hukou holders, which would increase the log-wages of the migrants by 0.409 (see Table $2 \mathrm{~b}$ ), would reduce the proportion of salaried migrants that want to be entrepreneurs by $16.4 \%\left(=0.403^{*} 0.409\right)$. This is a reduction by about one third of all current and want-to-be entrepreneurs.

\section{Conclusions}

In this paper we examine whether and how credit constraints are preventing rural-to-urban migrants in China from becoming entrepreneurs. We found that current migrants earn about $25 \%$ more as entrepreneurs than comparable migrants in the salaried sector. Current entrepreneurs expect a $30 \%$ pay drop should they become salary earners again. Even accounting for laboratory-measured risk attitudes, IQ, level of trust, and length of job tenure yields a similar level of a $20 \%$ anticipated increase in hourly earnings when becoming an entrepreneur.

When asked, current want-to-be entrepreneurs expect to need about 2.5 years of total yearly income as initial investment, coinciding with the nearly 2.5 years of income that the 68 migrants who became entrepreneurs in 2009 needed. Want-to-be entrepreneurs expect to be able to borrow no more than $40 \%$ of this initial sum, whereas the actual entrepreneurs have, even in recent years, been able to borrow no more than $25 \%$, mostly from family and friends. The estimated excess return to initial investments is $4.7 \%$ for migrants, though less than $1 \%$ for urban entrepreneurs, consistent with the idea that the migrant entrepreneurs are more credit constrained. Wantto-be entrepreneurs also turn out to be about $25 \%$ more likely than actual entrepreneurs or non-entrepreneurs to have experienced a credit constraining event in the previous year, such as the death of a family member.

In all, our paper gives credence to the idea that formal financial institutions are still in an embryonic stage of development in Chinese cities and that want-to-be entrepreneurs have to rely on their savings and their contacts to raise the capital they need to become entrepreneurs. As a result of the 
credit constraints, there are about as many salaried migrants who want to be entrepreneurs but who haven't yet got sufficient savings as there are actual migrant entrepreneurs: both make up about a quarter of the total population of migrant workers in the cities. Our partial equilibrium estimate is that GDP would increase by about $1 \%$ to $2.8 \%$ per year if all the want-to-be entrepreneurs did not face the credit constraints they do, though this figure might be considerably less if the earnings of entrepreneurs were to drop with a doubling of their numbers.

Short-term policy measures that could make a difference include financial reforms such that migrants would be able to use collateral in the countryside to borrow in the cities, as well as making it easier for migrants to stay in the cities long-term so that they can build the networks via which they can borrow more and attain the permits they need to become entrepreneurs.

Our paper also points to a, perhaps unanticipated, economic 'benefit' from legalized discrimination of migrants in urban areas: being barred from many of the more desirable jobs in the formal sector makes being an entrepreneur a more attractive proposition. We found that a $1 \%$ increase in the gap between the earnings of migrants and Urban Hukou holders in the salaried sector increases the proportion of wage-earning migrants that want to be an entrepreneur by $0.4 \%$ and that perhaps up to a third of the current and want-to-be entrepreneurs would cease to want to be an entrepreneur in the absence of discrimination. 


\section{References}

[1] Andersson, P., Wadensjo, E. (2006), "Do the unemployed become successful entrepreneurs? A comparison between the unemployed, inactive and wage-earners", IZA Discussion Paper 2402.

[2] Ardagna, S., and Lusardi A. (2008), "Explaining international differences in entrepreneurship: the role of individual characteristics and regulatory constraints", NBER Working Papers 14012.

[3] Ardagna, S., and Lusardi A. (2009), "Heterogeneity in the effect of regulation on entrepreneurship and entry size", NBER Working Papers 15510 .

[4] Astebro, T. and I. Bernhardt, 1999. "The Winner's Curse of HumanCapital", Discussion paper, Center for Economic Research, Canada.

[5] Banerjee, A., Duflo, E., Glennerster, R., and Kinnan, C. (2009), "The Miracle of Microfinance? Evidence from a Randomized Evaluation", MIT working Paper.

[6] Banerjee, A. and A. Newman, (1993). "Occupational choice and the process of development", Journal of Political Economy, 101(2), 274-298.

[7] Blanchflower, D. and A. Oswald, (1998). "What makes an entrepreneur?", Journal of Labor Economics, 16(1), 26-60.

[8] Blanchflower, D.G. (2004). "Self-Employment: More may not be better", NBER Working Papers 10286.

[9] Blau, M. (1985), "Self-employment and self-selection in developing country labour markets", Southern Economic Journal 52(2), pp. 351-63

[10] Blau, M. (1986), "Self-employment, earnings, and mobility in Peninsular Malaysia", World Development 14(7), pp. 839-52.

[11] Buera, F. (2009) "A dynamic model of entrepreneurship with borrowing constraints: theory and evidence," Annals of Finance, vol. 5(3), pages 443-464

[12] Dohmen, T., Falk, A., Huffman, D., Sunde, U., Schupp, J., and Wagner, G., (2005), "Individual risk attitudes: New evidence from a large, representative, experimentally-validated survey", IZA Discussion Papers, 1730 . 
[13] Luo, C., Frijters, P., Meng, X. (2010), "Child education and the family income gradient in China", RUMiCI working paper.

[14] Clark, K., Drinkwater, S. (2000), "Pushed out or pulled in? Selfemployment among ethnic minorities in England and Wales", Labour Economics 7, pp. 603-628

[15] Constant, A., Shachmurove, Y., and Zimmermann, K.F. (2003), "What makes an entrepreneur and does it pay?", IZA Discussion Paper 940.

[16] Dawson, C., Henley, A., and Latreille, P. (2009), "Why do individuals choose self-employment?", IZA Discussion Paper 3974.

[17] Djankov, S., La Porta, R., Lopez-de-Silanes, F. and Shleifer, A. (2002), "The Regulation of Entry", Quarterly Journal of Economics 117, 1-37

[18] Du, Y., Gregory, R.G., and Meng, X., 2006, "Impact of the guest worker system on poverty and wellbeing of migrant workers in urban China" in Ross Gaunaut and Ligang Song (eds.) The Turning Point in China's economic Development, Canberra: Asia Pacific Press.

[19] Dulleck, U., Frijters, P., and Winter-Ebmer, R. (2006), "Reducing Startup costs for New Firms: The Double Dividend on the Labor Market", Scandinavian Journal of Economics, 108(2), 317-338. Also IZA paper.

[20] Earle, J. S., and Zakova, Z. (1998). "Self-Employment in Transitional Economies: Entrepreneurship or Disguised Unemployment", paper presented at the OECD International Conference on Self-Employment. http://www.ciln.mcmaster.ca/papers/seconf/transecns.pdf.

[21] Evans, D. and B. Jovanovic, (1989). "An estimated model of entrepreneurial choice under liquidity constraints", Journal of Political Economy, $97,808-827$.

[22] Evans, D. and L. Leighton, (1989). "Some new empirical aspects of entrepreneurship" American Economic Review, 79, 519-535.

[23] Fairlie, R.W., Meyer, B.D., (2000), "Trends in self-employment among white and black men during the twentieth century", Journal of Human Resources, vol 35(4), pp. 643-69.

[24] Farrell, D. and Lund, S., (2006), "Putting China's capital to work", Far Eastern Economic Review, 169(4), pp. 5-10. 
[25] Fields, G. S. (1975), "Rural-Urban migration, urban unemployment and underemployment, and job-search activity in LDCs", Journal of Development Economics, 2(2), pp. 165-87.

[26] Fonseca, R., Michaud, P.C., and Sopraseuth, T. (2007) "Entrepreneurship, Wealth, Liquidity Constraints and Start-up Costs," IZA Discussion Papers 2874

[27] Glaeser, E.L. (2007), "Entrepreneurship and the city", NBER Working Papers 13551.

[28] Hamilton, B. H. (2000), "Does entrepreneurship pay? An empirical analysis of the returns to self-employment", Journal of Political Economy, vol 108(3), pp. 604-631.

[29] Hericourt, J. and Ponet, S., (2007), "FDI and credit constraints: firm level evidence in China", CEPII Working Paper No.2007-11, May.

[30] Holtz-Eakin, D., D. Joulfaian, and H. Rosen, (1994). "Entrepreneurial decisions and liquidity constraints", Rand Journal of Economic, 25, 334347.

[31] Hout, M., and Rosen, H. (2000), "Self-employment, family background, and race", Journal of Human Resources, vol 35(4), pp. 670-92.

[32] Hurst, E. and Lusardi, A., 2004. "Liquidity constraints, household wealth, and entrepreneurship", Journal of Political Economy, 112(2), 319-347.

[33] Iyer, L., Meng, X., Qian, N. (2010), "Unbundling property rights: urban housing privitization and labor mobility in China", IGOV working paper, Berkeley.

[34] Karlan, D. and Zinman, J. (2010) "Expanding Microenterprise Credit Access: Using Randomized Supply Decisions to Estimate the Impacts in Manila.", Review of Financial Studies, (23)1, pp. 433-464

[35] Kerr, W. and Nanda, R., 2009, "Financing constraints and entrepreneurship", NBER Working Paper 15498.

[36] Khander, S.R. (2005), "Microfinance and poverty: evidence using panel data from Bangladesh", World Bank Economic Review vol 19, pp. 263286. 
[37] Lal, D. (1973), "Disutility of effort, migration and the shadow wage rate", Oxford Economic Papers, 25(March): 112-26.

[38] Li, D.D., Liu, L. and Wang, H., (2009), "Changes in the labor share of GDP: a U-shaped curve", Social Sciences in China, 30(4), pp.131-153.

[39] Lofstrom, M. (2002), "Labor market assimilation and the selfemployment decision of immigrant entrepreneurs", Journal of Population Economics, 15(1), pp.83-114.

[40] Lofstrom, M. and C. Wang, (2007). "Mexican-Hispanic self-employment entry: The role of business start-up constraints", The Annals of the American Academy of Political and Social Science.

[41] Mazumdar, D. (1976), "The rural-urban wage gap, migration and the shadow-wage", Oxford Economic Papers, 28 (3), pp. 406-25.

[42] Mazumdar, D. (1977), "Analysis of the dual labour market in LDCs", in Kannappan, S. (ed.), Studies in Urban Labour Market Behaviour in Developing Areas, International Institute of labour Studies.

[43] Meng, X., 2000, Labour Market Reform in China, Cambridge: Cambridge University Press.

[44] Meng, X. and Manning, C., 2010, "The Great Migration in China and Indonesia - trend and institutions" in X. Meng and C. Manning, with S. Li, and T.Effendi (eds) The Great Migration: Rural-Urban Migration in China and Indonesia, Edward Elgar Publishing Ltd.

[45] Meng, X. and Zhang, J., 2001, "Two-tier labour markets in urban China: Occupational segregation and wage differentials between urban residents and rural migrants in Shanghai", Journal of Comparative Economics, 29, pp.485-504.

[46] Mesnard, A. (2004), "Temporary migration and capital market imperfections", Oxford Economic Papers, 56, pp. 242-62.

[47] Mesnard, A. and Ravallion, M. (2006), "The wealth effect on new business startups in a developing economy", Economica, 73, pp. 367-92.

[48] Mohapatra, Rozelle, S. S. and Goodhue, R. (2007), "The rise of selfemployment in rural China: Development or distress?", World Development, 35(1), 163-181. 
[49] Nanda, R., (2010), "Entrepreneurship and the discipline of external finance", Working Paper, Harvard Business School.

[50] Nykvist, J. (2008), "Entrepreneurship and liquidity constraints: evidence from Sweden", Scandinavian Journal of Economics 110(1), pp. 23-43.

[51] Perkins, D. and Yusuf, S. (1984), Rural Development in China, Johns Hopkins University Press, Maryland MD.

[52] Porta, R.L. and A. Shleifer (2008). "The Unofficial Economy and Economic Development," NBER Working Papers 14520

[53] Porter, M. E., Sachs, J. D., Warner, A. M, Cornelius, P. K., Levinson, M. and Schwab, K. (2000), The Global Competitiveness Report, World Economic Forum, Oxford University Press, New York

[54] Portes, A., and Zhou, M. (1996), "Self-employment and the earnings of immigrants", American Sociological Review, 61(2), pp. 219-230.

[55] Praag, M. van, Verlsoot, P.H. (2007), "What is the value of Entrepreneurship? A review of recent research", IZA Discussion Papers 3014

[56] Qian, Y., Djankov, S., Roland, G., and E. Zhuravskaya) (2006), "Who Are China's Entrepreneurs?", American Economic Review, Papers and Proceedings, 96(2), pp. 348-352.

[57] Sanders, J.M., Nee, V. (1996), "Immigrant self-employment: the family as social capital and the value of human capital", American Sociological Review, 61 (2), pp. 231-49.

[58] Todaro, M. P., (1969), "A Model of Labor Migration and Urban Unemployement in Less Developed Countries", Amrican Economic Review, 69, pp. 486-499.

[59] Wagner, J. (2005), "Nascent and infant entrepreneurs in Germany: evidence from the regional entrepreneurship monitor (REM)", IZA DP 1522.

[60] Wang, Shing-Yi (2010) "Credit Constraints, Job Mobility and Entrepreneurship: Evidence from a Property Reform in China", forthcoming Review of Economics and Statistics.

[61] West, L. and Yaohui Zhao (eds) (2000), Rural Labor Flows in China, University of California Press, Berkeley CA. 
[62] World Bank Investment Climate Survey, (2003), http://www.enterprisesurveys.org/rawdata.aspx. Washington DC: The World Bank.

[63] Yunus, Muhammad, (2006), Nobel laureat lecture, http://nobelprize.org/nobel_prizes/peace/laureates/2006/yunuslecture-en.html.

[64] Zhang, J., L. Zhang, S. Rozelle, and S. Boucher, (2006). "Selfemployment with Chinese characteristics: the forgotten engine of rural China's growth", Contemporary Economic Policy, 24(3), 446-458.

[65] Zhao, Y., (2000), "Rural-to-urban labor migration in China: the past and the present", in L. West and Y. Zhao (eds), Rural Labor Flows in China, University of California Press, Berkeley CA, pp. 15-33. 
Table 1A: Summary Statistics for the total sample

\begin{tabular}{|c|c|c|c|c|c|}
\hline \multirow[b]{2}{*}{ Panel A: Migrant workers } & \multicolumn{2}{|c|}{ Currently self-employed } & \multicolumn{2}{|c|}{ Current wage-salary earners } & \multirow[t]{2}{*}{$\underline{\underline{\text { Total }}}$} \\
\hline & Entrepreneurs & $\begin{array}{l}\text { Involuntary self- } \\
\text { employed }\end{array}$ & $\begin{array}{l}\text { "want-to-be" } \\
\text { entrepreneurs }\end{array}$ & $\begin{array}{l}\text { Happy to be } \\
\text { wage-salary } \\
\text { earners }\end{array}$ & \\
\hline Distribution in each group (\%) & 23.02 & 5.04 & 22.7 & 49.24 & 6789 \\
\hline Weekly hours worked (hours) & 77.08 & 79.33 & 58.39 & 56.81 & 62.97 \\
\hline Weekly hours (top coded) (hours) & 75.22 & 76.38 & 58.28 & 56.67 & 62.30 \\
\hline Monthly wage/net revenue (yuan) & 2410 & 1760 & 1648 & 1633 & 1822 \\
\hline Hourly wage/net revenue (yuan) & 8.36 & 6.13 & 7.33 & 7.42 & 7.55 \\
\hline Age & 35.90 & 36.88 & 28.33 & 31.21 & 31.92 \\
\hline Years of schooling & 8.38 & 8.23 & 9.83 & 9.50 & 9.26 \\
\hline Year since migration & 8.74 & 8.55 & 5.74 & 6.20 & 6.80 \\
\hline$\%$ being males & 57.39 & 52.92 & 65.41 & 59.53 & 60.04 \\
\hline Self assessed risk & 2.88 & 2.60 & 4.16 & 3.26 & 3.34 \\
\hline$\%$ indicated most people can be trusted & 38.13 & 33.92 & 50.86 & 47.95 & 45.60 \\
\hline Size of network & 24.46 & 22.27 & 28.35 & 23.37 & 24.70 \\
\hline Of which: \# living in the same city & 10.85 & 9.38 & 13.48 & 10.53 & 11.21 \\
\hline$\%$ had credit constraining events & 11.45 & 15.79 & 15.44 & 11.10 & 12.40 \\
\hline Self-employed real initial investment (yuan) & 28570 & 29377 & & & \\
\hline Hometown housing value (yuan) & 53611 & 35295 & 50531 & 50193 & 50306 \\
\hline Industry distribution: & $\%$ & $\%$ & $\%$ & $\%$ & Freq. \\
\hline Construction & 3.01 & 3.80 & 7.40 & 11.01 & 542 \\
\hline Manufacturing & 3.84 & 4.09 & 24.59 & 25.99 & 1322 \\
\hline Retail/wholesale & 64.24 & 66.96 & 19.99 & 15.82 & 2070 \\
\hline Services & 24.06 & 22.81 & 36.15 & 35.84 & 2209 \\
\hline High tech-edu & 4.41 & 2.05 & 4.61 & 4.88 & 310 \\
\hline Finance-insurance & 0.00 & 0.29 & 6.88 & 6.10 & 311 \\
\hline Other & 0.45 & 0.00 & 0.39 & 0.36 & 25 \\
\hline Panel B: Urban workers & Entrepreneurs & $\begin{array}{l}\text { Involuntary self- } \\
\text { employed }\end{array}$ & $\begin{array}{l}\text { "want-to-be" } \\
\text { entrepreneurs }\end{array}$ & $\begin{array}{l}\text { Prefer to be } \\
\text { wage-salary } \\
\text { earners }\end{array}$ & Total \\
\hline Distribution in each group (\%) & 8.00 & 0.77 & 3.35 & 87.88 & 6487 \\
\hline Weekly hours worked (hours) & 56.93 & 55.86 & 44.74 & 42.41 & 43.75 \\
\hline Weekly hours (top coded) (hours) & 56.85 & 55.86 & 44.74 & 42.41 & 43.75 \\
\hline Monthly wage/net revenue (yuan) & 3232 & 2468 & 2399 & 2628 & 2667 \\
\hline Hourly wage/net revenue (yuan) & 15.83 & 11.59 & 14.22 & 16.77 & 16.58 \\
\hline Age & 41.62 & 40.22 & 35.35 & 40.58 & 40.48 \\
\hline Years of schooling & 10.42 & 10.20 & 12.70 & 12.44 & 12.27 \\
\hline$\%$ being males & 61.08 & 54.00 & 60.37 & 56.10 & 56.61 \\
\hline Self assessed risk & 1.92 & 2.36 & 2.83 & 1.63 & 1.70 \\
\hline$\%$ indicated most people can be trusted & 49.52 & 56.00 & 51.61 & 45.92 & 46.54 \\
\hline Size of network & 31.32 & 36.46 & 43.11 & 34.21 & 34.29 \\
\hline Of which: \# living in the same city & 23.32 & 25.98 & 32.39 & 27.19 & 27.05 \\
\hline$\%$ had credit constraining events & 4.05 & 4.00 & 3.23 & 3.47 & 3.51 \\
\hline Self-employed real initial investment (yuan) & 31458 & 13703 & & & \\
\hline Industry distribution: & $\%$ & $\%$ & $\%$ & $\%$ & Freq. \\
\hline Construction & 5.39 & 0.00 & 6.91 & 3.75 & 257 \\
\hline Manufacturing & 11.37 & 6.00 & 14.29 & 22.03 & 1349 \\
\hline Retail/wholesale & 44.32 & 34.00 & 14.75 & 10.47 & 876 \\
\hline Services & 33.14 & 56.00 & 46.08 & 43.71 & 2792 \\
\hline High tech-edu & 3.47 & 2.00 & 7.37 & 12.95 & 773 \\
\hline Finance-insurance & 1.16 & 2.00 & 8.76 & 5.40 & 334 \\
\hline Other & 1.16 & 0.00 & 1.84 & 1.68 & 106 \\
\hline
\end{tabular}


Table 1B: Summary Statistics for the experimental sample

\begin{tabular}{|c|c|c|c|c|c|}
\hline & \multicolumn{2}{|c|}{ Currently self-employed } & \multicolumn{2}{|c|}{ Current wage-salary earners } & \multirow[t]{2}{*}{$\underline{\text { Total }}$} \\
\hline & Entrepreneurs & $\begin{array}{l}\text { Involuntary self- } \\
\text { employed }\end{array}$ & $\begin{array}{l}\text { "want-to-be" } \\
\text { entrepreneurs }\end{array}$ & $\begin{array}{l}\text { Happy to be wage- } \\
\text { salary earners }\end{array}$ & \\
\hline Distribution in each group (\%) & 15.51 & 5.17 & 28.50 & 50.81 & 1663 \\
\hline Weekly hours worked (hours) & 76.76 & 80.66 & 57.36 & 54.91 & 60.33 \\
\hline Weekly hours (top coded) (hours) & 75.05 & 77.57 & 57.30 & 54.82 & 59.84 \\
\hline Monthly wage/net revenue (yuan) & 2300 & 1567 & 1717 & 1660 & 1771 \\
\hline Hourly wage/net revenue (yuan) & 7.91 & 4.94 & 7.63 & 7.82 & 7.63 \\
\hline Age & 35.67 & 37.07 & 27.11 & 30.21 & 30.53 \\
\hline Years of schooling & 8.65 & 8.19 & 10.14 & 9.91 & 9.69 \\
\hline Year since migration & 8.26 & 7.78 & 5.63 & 6.07 & 6.37 \\
\hline$\%$ being males & 66.28 & 62.79 & 69.62 & 64.02 & 65.90 \\
\hline Self assessed risk & 3.84 & 3.37 & 4.79 & 4.13 & 4.24 \\
\hline$\%$ indicated most people can be trusted & 50.78 & 48.84 & 58.02 & 55.74 & 55.26 \\
\hline Size of network & 25.20 & 22.15 & 28.66 & 24.48 & 25.66 \\
\hline Of which: \# living in the same city & 10.44 & 7.81 & 14.00 & 10.77 & 11.49 \\
\hline$\%$ had credit constraining events & 11.24 & 16.28 & 14.77 & 11.24 & 12.51 \\
\hline Self-employed Initial investment (yuan) & 34339 & 57499 & & & \\
\hline Hometown housing value (yuan) & 56159 & 34217 & 50831 & 46802 & 48751 \\
\hline Industry distribution: & $\%$ & $\%$ & $\%$ & $\%$ & Freq. \\
\hline Construction & 3.01 & 3.80 & 7.40 & 11.01 & 542 \\
\hline Manufacturing & 3.84 & 4.09 & 24.59 & 25.99 & 1322 \\
\hline Retail/wholesale & 64.24 & 66.96 & 19.99 & 15.82 & 2070 \\
\hline Services & 24.06 & 22.81 & 36.15 & 35.84 & 2209 \\
\hline High tech-edu & 4.41 & 2.05 & 4.61 & 4.88 & 310 \\
\hline Finance-insurance & 0.00 & 0.29 & 6.88 & 6.10 & 311 \\
\hline Other & 0.45 & 0.00 & 0.39 & 0.36 & 25 \\
\hline
\end{tabular}


Table 2A: Earnings equations (hourly earnings)

\begin{tabular}{|c|c|c|c|c|c|c|c|c|c|}
\hline & \multicolumn{3}{|c|}{$\underline{\text { Panel A: Baseline model }}$} & \multicolumn{3}{|c|}{$\underline{\text { Panel B: Baseline+ initial investment }}$} & \multicolumn{3}{|c|}{$\begin{array}{l}\text { Panel C: Baseline+initial } \\
\text { invst.+(risk trust network) }\end{array}$} \\
\hline & $\begin{array}{l}\text { Total } \\
{[1]}\end{array}$ & $\begin{array}{l}\text { Migrants } \\
\text { [2] }\end{array}$ & $\begin{array}{l}\text { Urban } \\
{[3]}\end{array}$ & \begin{tabular}{|l} 
Total \\
{$[4]$}
\end{tabular} & $\begin{array}{l}\text { Migrants } \\
{[5]}\end{array}$ & $\begin{array}{l}\text { Urban } \\
{[6]}\end{array}$ & \begin{tabular}{|l} 
Total \\
{$[7]$}
\end{tabular} & $\begin{array}{l}\text { Migrants } \\
{[8]}\end{array}$ & $\begin{array}{l}\text { Urban } \\
{[9]}\end{array}$ \\
\hline Age & $\begin{array}{l}0.232 \\
{[0.115]^{* *}}\end{array}$ & $\begin{array}{l}0.361 \\
{[0.068]^{* * *}}\end{array}$ & $\begin{array}{l}0.822 \\
{[0.268]^{* * *}}\end{array}$ & $\begin{array}{l}0.225 \\
{[0.116]^{*}}\end{array}$ & $\begin{array}{l}0.353 \\
{[0.068]^{* * *}}\end{array}$ & $\begin{array}{l}0.820 \\
{[0.268]^{* * *}}\end{array}$ & $\mid \begin{array}{l}0.253 \\
{[0.116]^{* *}}\end{array}$ & $\begin{array}{l}0.355 \\
{[0.068]^{* * *}}\end{array}$ & $\begin{array}{l}0.859 \\
{[0.271]^{* * *}}\end{array}$ \\
\hline Age2 & $\begin{array}{l}-0.003 \\
{[0.001]^{*}}\end{array}$ & $\begin{array}{l}-0.005 \\
{[0.001]^{* * *}}\end{array}$ & $\begin{array}{l}-0.009 \\
{[0.003]^{* * *}}\end{array}$ & $\begin{array}{l}-0.003 \\
{[0.001]^{*}}\end{array}$ & $\begin{array}{l}-0.005 \\
{[0.001]^{* * *}}\end{array}$ & $\begin{array}{l}-0.009 \\
{[0.003]^{* * *}}\end{array}$ & $\begin{array}{l}-0.003 \\
{[0.001]^{* *}}\end{array}$ & $\begin{array}{l}-0.005 \\
{[0.001]^{* * *}}\end{array}$ & $\begin{array}{l}-0.009 \\
{[0.003]^{* * *}}\end{array}$ \\
\hline Years of schooling & $\begin{array}{l}0.926 \\
{[0.058]^{* * *}}\end{array}$ & $\begin{array}{l}0.390 \\
{[0.039]^{* * *}}\end{array}$ & $\begin{array}{l}1.239 \\
{[0.102]^{* * *}}\end{array}$ & $\begin{array}{l}0.924 \\
{[0.058]^{* * *}}\end{array}$ & $\begin{array}{l}0.386 \\
{[0.039]^{* * *}}\end{array}$ & $\begin{array}{l}1.239 \\
{[0.102]^{* * *}}\end{array}$ & \begin{tabular}{|l}
0.878 \\
{$[0.059]^{* * *}$}
\end{tabular} & $\begin{array}{l}0.349 \\
{[0.039]^{* * *}}\end{array}$ & $\begin{array}{l}1.193 \\
{[0.103]^{* * *}}\end{array}$ \\
\hline Dummy for males & $\begin{array}{l}2.618 \\
{[0.327]^{* * *}}\end{array}$ & $\begin{array}{l}1.648 \\
{[0.196]^{* * *}}\end{array}$ & $\begin{array}{l}4.034 \\
{[0.625]^{* * *}}\end{array}$ & $\begin{array}{l}2.596 \\
{[0.327]^{* * *}}\end{array}$ & $\begin{array}{l}1.600 \\
{[0.195]^{* * *}}\end{array}$ & $\begin{array}{l}4.030 \\
{[0.625]^{* * *}}\end{array}$ & $\begin{array}{l}2.590 \\
{[0.329]^{* * *}}\end{array}$ & $\begin{array}{l}1.528 \\
{[0.195]^{* * *}}\end{array}$ & $\begin{array}{l}4.027 \\
{[0.641]^{* * *}}\end{array}$ \\
\hline Dummy for married & $\begin{array}{l}2.182 \\
{[0.503]^{* * *}}\end{array}$ & $\begin{array}{l}0.314 \\
{[0.284]}\end{array}$ & $\begin{array}{l}2.652 \\
{[1.036]^{* *}}\end{array}$ & $\begin{array}{l}2.185 \\
{[0.504]^{* * *}}\end{array}$ & $\begin{array}{l}0.300 \\
{[0.283]}\end{array}$ & $\begin{array}{l}2.656 \\
{[1.036]^{* *}}\end{array}$ & \begin{tabular}{|l}
2.075 \\
{$[0.504]^{* * *}$}
\end{tabular} & $\begin{array}{l}0.383 \\
{[0.285]}\end{array}$ & $\begin{array}{l}2.421 \\
{[1.041]^{* *}}\end{array}$ \\
\hline Dummy for migrants & $\begin{array}{l}-5.655 \\
{[0.447]^{* * *}}\end{array}$ & & & \begin{tabular}{|l}
-5.687 \\
{$[0.448]^{* * *}$}
\end{tabular} & & & $\begin{array}{l}-5.264 \\
{[0.476]^{* * *}}\end{array}$ & & \\
\hline Dummy for entrepreneurs & $\begin{array}{l}1.188 \\
{[0.843]}\end{array}$ & $\begin{array}{l}1.986 \\
{[0.254]^{* * *}}\end{array}$ & $\begin{array}{l}1.841 \\
{[1.171]}\end{array}$ & $\begin{array}{l}0.915 \\
{[0.849]}\end{array}$ & $\begin{array}{l}1.693 \\
{[0.256]^{* * *}}\end{array}$ & $\begin{array}{l}1.755 \\
{[1.191]}\end{array}$ & \begin{tabular}{|l}
0.980 \\
{$[0.847]$}
\end{tabular} & $\begin{array}{l}1.656 \\
{[0.255]^{* * *}}\end{array}$ & $\begin{array}{l}1.835 \\
{[1.192]}\end{array}$ \\
\hline Dummy for mig*entrepreneurs & $\begin{array}{l}1.613 \\
{[0.989]}\end{array}$ & & & $\begin{array}{l}1.684 \\
{[0.991]^{*}}\end{array}$ & & & $\begin{array}{l}1.552 \\
{[0.989]}\end{array}$ & & \\
\hline Real Initial investment $/ 10^{5}$ & & & & \begin{tabular}{|l}
0.892 \\
{$[0.295]^{* * *}$}
\end{tabular} & $\begin{array}{l}1.208 \\
{[0.155]^{* * *}}\end{array}$ & $\begin{array}{l}0.254 \\
{[0.658]}\end{array}$ & \begin{tabular}{|l}
0.851 \\
{$[0.294]^{* * *}$}
\end{tabular} & $\begin{array}{l}1.190 \\
{[0.154]^{* * *}}\end{array}$ & $\begin{array}{l}0.186 \\
{[0.658]}\end{array}$ \\
\hline Risk loving & & & & & & & $\begin{array}{l}0.087 \\
{[0.074]}\end{array}$ & $\begin{array}{l}0.076 \\
{[0.041]^{*}}\end{array}$ & $\begin{array}{l}0.002 \\
{[0.161]}\end{array}$ \\
\hline Trusting & & & & & & & $\begin{array}{l}-0.043 \\
{[0.399]}\end{array}$ & $\begin{array}{l}0.192 \\
{[0.207]}\end{array}$ & $\begin{array}{l}-0.232 \\
{[0.933]}\end{array}$ \\
\hline Size of the social network in the city & & & & & & & $\begin{array}{l}0.045 \\
{[0.007]^{* * *}}\end{array}$ & $\begin{array}{l}0.048 \\
{[0.006]^{* * *}}\end{array}$ & $\begin{array}{l}0.043 \\
{[0.011]^{* * *}}\end{array}$ \\
\hline Industry dummies & Yes & Yes & Yes & Yes & Yes & Yes & Yes & Yes & Yes \\
\hline Region & Yes & Yes & Yes & Yes & Yes & Yes & Yes & Yes & Yes \\
\hline Observations & 13280 & 6789 & 6491 & 13280 & 6789 & 6491 & 13280 & 6789 & 6491 \\
\hline R-squared & 0.12 & 0.08 & 0.09 & 0.12 & 0.09 & 0.09 & 0.12 & 0.10 & 0.09 \\
\hline
\end{tabular}

* significant at $10 \% ;{ }^{* *}$ significant at $5 \% ;{ }^{* * *}$ significant at $1 \%$; Standard errors in brackets.

Note: (1) The level of initial investment is in real terms using provincial CPI (1995=100); (2) missing values for risk and network are set to zero and the dummy variables for those missing value observations are included in the regression. (3) hours are top coded at 91 hours per week ( 13 hours daily, 7 days a week). 
Table 2B: Earnings equations (log hourly earnings)

\begin{tabular}{|c|c|c|c|c|c|c|c|c|c|}
\hline & \multicolumn{3}{|c|}{ Panel A: Baseline model } & \multicolumn{3}{|c|}{$\underline{\text { Panel B: Baseline+ initial investment }}$} & \multicolumn{3}{|c|}{$\begin{array}{c}\text { Panel C: Baseline+initial } \\
\text { invst.+(risk trust network) }\end{array}$} \\
\hline & $\begin{array}{l}\text { Total } \\
{[1]}\end{array}$ & $\begin{array}{l}\text { Migrants } \\
{[2]}\end{array}$ & $\begin{array}{l}\text { Urban } \\
{[3]}\end{array}$ & $\begin{array}{l}\text { Total } \\
{[4]}\end{array}$ & $\begin{array}{l}\text { Migrants } \\
{[5]}\end{array}$ & $\begin{array}{l}\text { Urban } \\
{[6]}\end{array}$ & $\mid \begin{array}{l}\text { Total } \\
{[7]}\end{array}$ & $\begin{array}{l}\text { Migrants } \\
{[8]}\end{array}$ & $\begin{array}{l}\text { Urban } \\
{[9]}\end{array}$ \\
\hline Age & $\begin{array}{l}0.027 \\
{[0.004]^{* * *}}\end{array}$ & $\begin{array}{l}0.050 \\
{[0.005]^{* * *}}\end{array}$ & $\begin{array}{l}0.050 \\
{[0.007]^{* * *}}\end{array}$ & $\mid \begin{array}{l}0.027 \\
{[0.004]^{* * *}}\end{array}$ & $\begin{array}{l}0.049 \\
{[0.005]^{* * *}}\end{array}$ & $\begin{array}{l}0.050 \\
{[0.007]^{* * *}}\end{array}$ & $\begin{array}{l}0.029 \\
{[0.004]^{* * *}}\end{array}$ & $\begin{array}{l}0.049 \\
{[0.005]^{* * *}}\end{array}$ & $\begin{array}{l}0.052 \\
{[0.007]^{* * *}}\end{array}$ \\
\hline Age2 & $\begin{array}{l}-0.000 \\
{[0.000]^{* * *}}\end{array}$ & $\begin{array}{l}-0.001 \\
{[0.000]^{* * *}}\end{array}$ & $\begin{array}{l}-0.001 \\
{[0.000]^{* * *}}\end{array}$ & {$\left[\begin{array}{l}-0.000 \\
{[0.000]^{* * *}}\end{array}\right.$} & $\begin{array}{l}-0.001 \\
{[0.000]^{* * *}}\end{array}$ & $\begin{array}{l}-0.001 \\
{[0.000]^{* * *}}\end{array}$ & $\begin{array}{l}0.000 \\
{[0.000]^{* * *}}\end{array}$ & $\begin{array}{l}-0.001 \\
{[0.000]^{* * *}}\end{array}$ & $\begin{array}{l}-0.001 \\
{[0.000]^{* * *}}\end{array}$ \\
\hline Years of schooling & $\begin{array}{l}0.063 \\
{[0.002]^{* * *}}\end{array}$ & $\begin{array}{l}0.048 \\
{[0.003]^{* * *}}\end{array}$ & $\begin{array}{l}0.072 \\
{[0.003]^{* * *}}\end{array}$ & {$\left[\begin{array}{l}0.063 \\
{[0.002]^{* * *}}\end{array}\right.$} & $\begin{array}{l}0.048 \\
{[0.003]^{* * *}}\end{array}$ & $\begin{array}{l}0.072 \\
{[0.003]^{* * *}}\end{array}$ & $\begin{array}{l}0.060 \\
{[0.002]^{* * *}}\end{array}$ & $\begin{array}{l}0.046 \\
{[0.003]^{* * *}}\end{array}$ & $\begin{array}{l}0.068 \\
{[0.003]^{* * *}}\end{array}$ \\
\hline Dummy for males & $\begin{array}{l}0.190 \\
{[0.011]^{* * *}}\end{array}$ & $\begin{array}{l}0.150 \\
{[0.015]^{* * *}}\end{array}$ & $\begin{array}{l}0.243 \\
{[0.017]^{* * *}}\end{array}$ & {$\left[\begin{array}{l}0.189 \\
{[0.011]^{* * *}}\end{array}\right.$} & $\begin{array}{l}0.147 \\
{[0.015]^{* * *}}\end{array}$ & $\begin{array}{l}0.243 \\
{[0.017]^{* * *}}\end{array}$ & $\begin{array}{l}0.183 \\
{[0.011]^{* * *}}\end{array}$ & $\begin{array}{l}0.141 \\
{[0.015]^{* * *}}\end{array}$ & $\begin{array}{l}0.232 \\
{[0.017]^{* * *}}\end{array}$ \\
\hline Dummy for married & $\begin{array}{l}0.109 \\
{[0.017]^{* * *}}\end{array}$ & $\begin{array}{l}0.018 \\
{[0.021]}\end{array}$ & $\begin{array}{l}0.160 \\
{[0.028]^{* * *}}\end{array}$ & {$\left[\begin{array}{l}0.109 \\
{[0.017]^{* * *}}\end{array}\right.$} & $\begin{array}{l}0.016 \\
{[0.021]}\end{array}$ & $\begin{array}{l}0.160 \\
{[0.028]^{* * *}}\end{array}$ & $\begin{array}{l}0.104 \\
{[0.017]^{* * *}}\end{array}$ & $\begin{array}{l}0.025 \\
{[0.021]}\end{array}$ & $\begin{array}{l}0.144 \\
{[0.028]^{* * *}}\end{array}$ \\
\hline Dummy for migrants & $\begin{array}{l}-0.409 \\
{[0.016]^{* * *}}\end{array}$ & & & $\begin{array}{l}-0.412 \\
{[0.016]^{* * *}}\end{array}$ & & & $\begin{array}{l}-0.385 \\
{[0.016]^{* * *}}\end{array}$ & & \\
\hline Dummy for entrepreneurs & $\begin{array}{l}-0.012 \\
{[0.029]}\end{array}$ & $\begin{array}{l}0.052 \\
{[0.019]^{* * *}}\end{array}$ & $\begin{array}{l}0.020 \\
{[0.032]}\end{array}$ & $\begin{array}{l}-0.032 \\
{[0.029]}\end{array}$ & $\begin{array}{l}0.033 \\
{[0.019]^{*}}\end{array}$ & $\begin{array}{l}0.007 \\
{[0.032]}\end{array}$ & $\begin{array}{l}-0.027 \\
{[0.029]}\end{array}$ & $\begin{array}{l}0.030 \\
{[0.019]}\end{array}$ & $\begin{array}{l}0.013 \\
{[0.032]}\end{array}$ \\
\hline Dummy for migrants*entrepreneurs & $\begin{array}{l}0.081 \\
{[0.034]^{* *}}\end{array}$ & & & $\begin{array}{l}0.086 \\
{[0.034]^{* *}}\end{array}$ & & & $\begin{array}{l}0.077 \\
{[0.034]^{* *}}\end{array}$ & & \\
\hline Initial investment $/ 10^{5}$ & & & & $\begin{array}{l}0.066 \\
{[0.010] * * *}\end{array}$ & $\begin{array}{l}0.078 \\
{[0.012]^{* * *}}\end{array}$ & $\begin{array}{l}0.038 \\
{[0.018]^{* *}}\end{array}$ & $\begin{array}{l}0.062 \\
{[0.010]^{* * *}}\end{array}$ & $\begin{array}{l}0.077 \\
{[0.012]^{* * *}}\end{array}$ & $\begin{array}{l}0.032 \\
{[0.018]^{*}}\end{array}$ \\
\hline Risk loving & & & & & & & $\begin{array}{l}0.015 \\
{[0.003]^{* * *}}\end{array}$ & $\begin{array}{l}0.008 \\
{[0.003]^{* *}}\end{array}$ & $\begin{array}{l}0.017 \\
{[0.004]^{* * *}}\end{array}$ \\
\hline Trusting & & & & & & & $\mid \begin{array}{l}0.020 \\
{[0.014]}\end{array}$ & $\begin{array}{l}0.003 \\
{[0.016]}\end{array}$ & $\begin{array}{l}0.070 \\
{[0.025]^{* * *}}\end{array}$ \\
\hline Size of the social network in the city & & & & & & & $\begin{array}{l}0.003 \\
{[0.000]^{* * *}}\end{array}$ & $\begin{array}{l}0.003 \\
{[0.000]^{* * *}}\end{array}$ & $\begin{array}{l}0.003 \\
{[0.000]^{* * *}}\end{array}$ \\
\hline Industry dummies & Yes & Yes & Yes & Yes & Yes & Yes & Yes & Yes & Yes \\
\hline Region & Yes & Yes & Yes & Yes & Yes & Yes & Yes & Yes & Yes \\
\hline Observations & 13280 & 6789 & 6491 & 13280 & 6789 & 6491 & 13280 & 6789 & 6491 \\
\hline R-squared & 0.36 & 0.21 & 0.29 & 0.36 & 0.21 & 0.30 & 0.37 & 0.22 & 0.31 \\
\hline
\end{tabular}

* significant at $10 \% ;{ }^{* *}$ significant at $5 \% ;{ }^{* *}$ significant at $1 \%$; Standard errors in brackets.

Note: (1) The level of initial investment is in real terms using provincial CPI (1995=100); (2) missing values for risk and network are set to zero and the dummy variables for those missing value observations are included in the regression. (3) hours are top coded at 91 hours per week ( 13 hours daily, 7 days a week). 
Table 3a: Actual and predicted absolute earnings

\begin{tabular}{|c|c|c|c|c|c|c|c|c|c|}
\hline & & \multicolumn{2}{|c|}{ Entrepreneurs } & \multicolumn{2}{|c|}{$\begin{array}{l}\text { Involuntary self- } \\
\text { employed }\end{array}$} & \multicolumn{2}{|c|}{$\begin{array}{l}\text { "want-to-be" } \\
\text { entrepreneurs }\end{array}$} & \multicolumn{2}{|c|}{$\begin{array}{c}\text { Happy to be wage-salary } \\
\text { earners }\end{array}$} \\
\hline & & Mean & $\%$ of actual & Mean & $\%$ of actual & Mean & $\%$ of actual & Mean & $\%$ of actual \\
\hline & Actual & 8.36 & & 6.13 & & 7.33 & & 7.42 & \\
\hline & & $(13.60)$ & & $(6.21)$ & & $(5.22)$ & & (4.63) & \\
\hline \multirow[t]{2}{*}{ [2] } & Own est. of earnings as wage-salary earners & 5.63 & 67.38 & 5.64 & 92.03 & & & & \\
\hline & & $(14.98)$ & & (12.57) & & & & & \\
\hline \multirow[t]{2}{*}{ [3] } & Predicted hourly earnings (self-employed) & & & & & 10.34 & 141.13 & 9.82 & 132.43 \\
\hline & & & & & & $(5.94)$ & & $(5.16)$ & \\
\hline \multirow[t]{2}{*}{ [4] } & Predicted hourly earnings (wage-salary earners) & 6.60 & 78.95 & 6.21 & 101.34 & & & & \\
\hline & & $(2.05)$ & & $(2.03)$ & & & & & \\
\hline
\end{tabular}

Note: Standard diviations are reported in parentheses. 
Table 3b: Earnings equations for the experimental sample

\begin{tabular}{|c|c|c|c|c|c|c|}
\hline & \multicolumn{3}{|c|}{ "Hourly earnings (yuan) } & \multicolumn{3}{|c|}{ Log (hourly earnings) } \\
\hline & Model 1 & Model 2 & Model 3 & Model 1 & Model 2 & Model 3 \\
\hline Age/10 & $\begin{array}{l}0.249 \\
{[0.087]^{* * *}}\end{array}$ & $\begin{array}{l}0.247 \\
{[0.087]^{* * *}}\end{array}$ & $\begin{array}{l}0.249 \\
{[0.087]^{* * *}}\end{array}$ & $\begin{array}{l}0.039 \\
{[0.009]^{* * *}}\end{array}$ & $\begin{array}{l}0.039 \\
{[0.009]^{* * *}}\end{array}$ & $\begin{array}{l}0.039 \\
{[0.009]^{* * *}}\end{array}$ \\
\hline$(\text { Age } / 10)^{2}$ & $\begin{array}{l}-0.004 \\
{[0.001]^{* * *}}\end{array}$ & $\begin{array}{l}-0.004 \\
{[0.001]^{* * *}}\end{array}$ & $\begin{array}{l}-0.004 \\
{[0.001]^{* * *}}\end{array}$ & $\begin{array}{l}-0.001 \\
{[0.000]^{* * *}}\end{array}$ & $\begin{array}{l}-0.001 \\
{[0.000]^{* * *}}\end{array}$ & $\begin{array}{l}-0.001 \\
{[0.000]^{* * *}}\end{array}$ \\
\hline Years of schooling & $\begin{array}{l}0.455 \\
{[0.051]^{* * *}}\end{array}$ & $\begin{array}{l}0.452 \\
{[0.051]^{* * *}}\end{array}$ & $\begin{array}{l}0.422 \\
{[0.053]^{* * *}}\end{array}$ & $\begin{array}{l}0.052 \\
{[0.005]^{* * *}}\end{array}$ & $\begin{array}{l}0.052 \\
{[0.005]^{* * *}}\end{array}$ & $\begin{array}{l}0.047 \\
{[0.006]^{* * *}}\end{array}$ \\
\hline Dummy for males & $\begin{array}{l}1.021 \\
{[0.264]^{* * *}}\end{array}$ & $\begin{array}{l}0.998 \\
{[0.264]^{* * *}}\end{array}$ & $\begin{array}{l}0.970 \\
{[0.268]^{* * *}}\end{array}$ & $\begin{array}{l}0.124 \\
{[0.028]^{* * *}}\end{array}$ & $\begin{array}{l}0.122 \\
{[0.028]^{* * *}}\end{array}$ & $\begin{array}{l}0.118 \\
{[0.029]^{* * *}}\end{array}$ \\
\hline Dummy for married & $\begin{array}{l}0.711 \\
{[0.346]^{* *}}\end{array}$ & $\begin{array}{l}0.685 \\
{[0.345]^{* *}}\end{array}$ & $\begin{array}{l}0.704 \\
{[0.345]^{* *}}\end{array}$ & $\begin{array}{l}0.056 \\
{[0.037]}\end{array}$ & $\begin{array}{l}0.053 \\
{[0.037]}\end{array}$ & $\begin{array}{l}0.056 \\
{[0.037]}\end{array}$ \\
\hline Dummy for entrepreneurs & $\begin{array}{l}1.914 \\
{[0.369]^{* * *}}\end{array}$ & $\begin{array}{l}1.801 \\
{[0.372]^{* * *}}\end{array}$ & $\begin{array}{l}1.798 \\
{[0.372]^{* * *}}\end{array}$ & $\begin{array}{l}0.130 \\
{[0.039]^{* * *}}\end{array}$ & $\begin{array}{l}0.119 \\
{[0.040]^{* * *}}\end{array}$ & $\begin{array}{l}0.120 \\
{[0.040]^{* * *}}\end{array}$ \\
\hline Real initial investment $/ 10^{5}$ & & $\begin{array}{l}0.511 \\
{[0.140]^{* * *}}\end{array}$ & $\begin{array}{l}0.501 \\
{[0.140]^{* * *}}\end{array}$ & & $\begin{array}{l}0.043 \\
{[0.015]^{* * *}}\end{array}$ & $\begin{array}{l}0.042 \\
{[0.015]^{* * *}}\end{array}$ \\
\hline IQ score & & & $\begin{array}{l}0.011 \\
{[0.012]}\end{array}$ & & & $\begin{array}{l}0.002 \\
{[0.001]}\end{array}$ \\
\hline Risk & & & $\begin{array}{l}-0.057 \\
{[0.038]}\end{array}$ & & & $\begin{array}{l}-0.003 \\
{[0.004]}\end{array}$ \\
\hline Trust & & & $\begin{array}{l}-0.044 \\
{[0.029]}\end{array}$ & & & $\begin{array}{l}-0.003 \\
{[0.003]}\end{array}$ \\
\hline Size of social network in cities & & & $\begin{array}{l}0.021 \\
{[0.008]^{* * *}}\end{array}$ & & & $\begin{array}{l}0.003 \\
{[0.001]^{* * *}}\end{array}$ \\
\hline Industry dummies & Yes & Yes & Yes & Yes & Yes & Yes \\
\hline Region & Yes & Yes & Yes & Yes & Yes & Yes \\
\hline Observations & 1662 & 1662 & 1662 & 1662 & 1662 & 1662 \\
\hline R-squared & 0.20 & 0.20 & 0.21 & 0.28 & 0.28 & 0.29 \\
\hline
\end{tabular}

* significant at $10 \%$; ${ }^{* *}$ significant at $5 \% ;{ }^{* * *}$ significant at $1 \%$; Standard errors in brackets.

Note: (1) The level of initial investment is in real terms using provincial CPI (1995=100); (2) hours are top coded at 91 hours per week ( 13 hours daily, 7 days a week). 


\begin{tabular}{|c|c|c|c|c|}
\hline \multirow{2}{*}{ Panel A: } & $\begin{array}{l}\text { Entrepreneurs vs. } \\
\text { total wage-salary } \\
\text { earners }\end{array}$ & $\begin{array}{l}\text { Entrepreneurs \& } \\
\text { happy-to-be w-s } \\
\text { earners }\end{array}$ & $\begin{array}{l}\text { Entrepreneurs vs. } \\
\text { want-to-be }\end{array}$ & $\begin{array}{l}\text { Want-to-be vs. } \\
\text { happy-to-be w-s } \\
\text { earners }\end{array}$ \\
\hline & {$[1]$} & {$[2]$} & [3] & {$[4]$} \\
\hline \multirow[t]{2}{*}{ Age/10 } & $0.261 * * *$ & $0.322 * * *$ & $0.377^{* * *}$ & $0.143^{* *}$ \\
\hline & {$[0.041]$} & {$[0.054]$} & [0.089] & {$[0.056]$} \\
\hline \multirow[t]{2}{*}{$(\text { Age } / 10)^{2}$} & $-0.033 * * *$ & $-0.043 * * *$ & $-0.037 * * *$ & $-0.030 * * *$ \\
\hline & {$[0.005]$} & [0.007] & [0.012] & {$[0.008]$} \\
\hline \multirow[t]{2}{*}{ Year since migration/10 } & $0.151 * * *$ & $0.194^{* * *}$ & $0.179 * * *$ & 0.023 \\
\hline & {$[0.024]$} & [0.032] & {$[0.051]$} & {$[0.034]$} \\
\hline \multirow[t]{2}{*}{$(\text { Year since migration } / 10)^{2}$} & $-0.048 * * *$ & $-0.064 * * *$ & $-0.052^{* *}$ & -0.015 \\
\hline & {$[0.010]$} & [0.013] & {$[0.022]$} & [0.015] \\
\hline \multirow[t]{2}{*}{ Year of schooling } & $-0.017 * * *$ & $-0.022 * * *$ & $-0.025 * * *$ & 0.003 \\
\hline & [0.002] & [0.003] & [0.005] & [0.003] \\
\hline \multirow[t]{2}{*}{ Dummy for males } & $-0.020 *$ & -0.007 & $-0.069 * * *$ & $0.043^{* * *}$ \\
\hline & {$[0.011]$} & [0.014] & [0.022] & [0.014] \\
\hline \multirow[t]{2}{*}{ Dummy for married } & $0.161 * * *$ & $0.216 * * *$ & $0.258 * * *$ & 0.027 \\
\hline & [0.014] & [0.018] & [0.029] & {$[0.020]$} \\
\hline \multirow[t]{2}{*}{ Self assessed risk } & 0.003 & $0.008 * *$ & -0.006 & $0.017^{* * *}$ \\
\hline & [0.002] & [0.003] & [0.005] & [0.003] \\
\hline \multirow[t]{2}{*}{ Believe most people can be trusted } & $-0.039 * * *$ & $-0.059 * * *$ & $-0.046 * *$ & $-0.037 * *$ \\
\hline & {$[0.012]$} & {$[0.016]$} & [0.023] & {$[0.015]$} \\
\hline \multirow[t]{2}{*}{ Network in cities } & $0.006^{*}$ & $0.012 * *$ & 0.002 & $0.011 * * *$ \\
\hline & [0.003] & {$[0.005]$} & [0.007] & {$[0.004]$} \\
\hline \multirow[t]{2}{*}{ Hometown housing value $/ 10^{4}$} & $0.002 * * *$ & $0.002 * *$ & $0.003^{* *}$ & -0.001 \\
\hline & {$[0.001]$} & [0.001] & [0.001] & {$[0.001]$} \\
\hline \multirow[t]{2}{*}{ Credit constraining events } & $-0.031 * *$ & -0.023 & $-0.106 * * *$ & $0.064 * * *$ \\
\hline & {$[0.014]$} & {$[0.021]$} & {$[0.030]$} & {$[0.021]$} \\
\hline City dummies & Yes & Yes & Yes & Yes \\
\hline Observations & 6471 & 4928 & 3117 & 4897 \\
\hline Pseudo R-squared & 0.20 & 0.19 & 0.28 & 0.07 \\
\hline LR Chi2 & 1402.97 & 1194.96 & 1203.60 & 443.00 \\
\hline \multicolumn{5}{|c|}{ Panel B: Controlling for mental health and length of time worked continously last year in the city: } \\
\hline \multirow[t]{2}{*}{ Credit constraining events } & $-0.029 * *$ & -0.022 & $-0.102 * * *$ & $0.061 * * *$ \\
\hline & [0.014] & [0.021] & {$[0.030]$} & [0.021] \\
\hline \multirow[t]{2}{*}{ Mental health } & -0.002 & -0.001 & $-0.008 * * *$ & $0.006^{* * *}$ \\
\hline & [0.001] & [0.002] & [0.002] & [0.002] \\
\hline \multirow[t]{2}{*}{ \# of months worked last year in the city } & $0.013^{* * *}$ & $0.018 * * *$ & $0.014 *$ & 0.005 \\
\hline & [0.004] & {$[0.005]$} & [0.008] & [0.004] \\
\hline
\end{tabular}

Standard errors in brackets

* significant at $10 \%$; ** significant at $5 \%$; *** significant at $1 \%$

Self assessed risk (higher the value, more risk loving) 
Table 5: Tests of sensitivity on alternative credit-constraining event measures

\begin{tabular}{|c|c|c|c|c|c|}
\hline & & $\begin{array}{l}\text { Entrepreneurs vs. total } \\
\text { wage-salary earners }\end{array}$ & $\begin{array}{l}\text { Entrepreneurs \& happy- } \\
\text { to-be w-s earners }\end{array}$ & $\begin{array}{l}\text { Entrepreneurs vs. want- } \\
\text { to-be }\end{array}$ & $\begin{array}{l}\text { Want-to-be vs. happy- } \\
\text { to-be w-s earners }\end{array}$ \\
\hline \multirow[t]{2}{*}{ [1] } & No. of four events occurred in the past year & $-0.027^{* *}$ & -0.018 & $-0.093 * * *$ & $0.055^{* * *}$ \\
\hline & & {$[0.013]$} & {$[0.018]$} & [0.024] & {$[0.016]$} \\
\hline \multirow[t]{2}{*}{ [2] } & Any of the three events occurred in the past year & -0.018 & -0.006 & $-0.086^{* *}$ & $0.054^{* *}$ \\
\hline & & {$[0.018]$} & [0.025] & {$[0.036]$} & {$[0.026]$} \\
\hline \multirow[t]{2}{*}{ [3] } & No. of the three events occurred in the past year & -0.022 & -0.010 & $-0.093 * * *$ & $0.055^{* *}$ \\
\hline & & {$[0.016]$} & [0.023] & {$[0.032]$} & {$[0.021]$} \\
\hline \multirow[t]{2}{*}{ [4] } & Any of the two events occurred in the past year & -0.017 & 0.000 & $-0.100 * * *$ & $0.072^{* * *}$ \\
\hline & & {$[0.018]$} & {$[0.026]$} & {$[0.036]$} & {$[0.027]$} \\
\hline \multirow[t]{3}{*}{ [5] } & No. of the two events occurred in the past year & -0.021 & -0.004 & $-0.102 * * *$ & $0.069 * * *$ \\
\hline & & {$[0.017]$} & {$[0.024]$} & [0.033] & {$[0.022]$} \\
\hline & Unexpected events: & & & & \\
\hline \multirow[t]{2}{*}{ [6] } & Any of the 4 event occured, all unexpected & -0.033 & -0.023 & $-0.127 * * *$ & $0.080^{* *}$ \\
\hline & & {$[0.020]$} & {$[0.030]$} & {$[0.041]$} & {$[0.032]$} \\
\hline \multirow[t]{2}{*}{ [7] } & Any of the 3 event occured, all unexpected & $-0.039 *$ & -0.027 & $-0.145^{* * *}$ & $0.089 * * *$ \\
\hline & & [0.021] & {$[0.032]$} & [0.042] & [0.033] \\
\hline \multirow[t]{4}{*}{ [8] } & Any of the 2 event occured, all unexpected & $-0.040^{*}$ & -0.027 & $-0.150 * * *$ & $0.097^{* * *}$ \\
\hline & & {$[0.021]$} & {$[0.032]$} & {$[0.042]$} & {$[0.034]$} \\
\hline & Observations & 6471 & 4928 & 3117 & 4897 \\
\hline & Control for mental health and length of worked & & & & \\
\hline \multirow[t]{3}{*}{ [9] } & Any of the 2 event occured, all unexpected & $-0.041^{* *}$ & -0.030 & $-0.152 * * *$ & $0.095^{* * *}$ \\
\hline & & [0.021] & {$[0.032]$} & {$[0.042]$} & [0.034] \\
\hline & Observations & 6471 & 4928 & 3117 & 4897 \\
\hline
\end{tabular}

*** $\mathrm{p}<0.01, * * \mathrm{p}<0.05, * \mathrm{p}<0.1 ;$ Standard errors in brackets

Note: 1. "four events" including: 1) marriage breakdown; 2) serious illness in the family; 3) death in the family; and 4) built or bought new house.

2. "three events" exclude "built or bought new house" from the credit-constraint-related events.

3. "two events" further exclude "marriage breakdown" from the credit-constraint-related events. 
Table 6: The level of initial investment and the proportion that can be borrowed from various channels

\begin{tabular}{|c|c|c|c|c|c|c|c|}
\hline & \multirow{2}{*}{\multicolumn{2}{|c|}{ Want-to-be entrepreneurs }} & \multirow{2}{*}{ [1] } & \multicolumn{4}{|c|}{ Current entrepreneurs } \\
\hline & & & & \multicolumn{2}{|c|}{ Total Average [2] } & \multicolumn{2}{|c|}{ Average 2009 investment [3] } \\
\hline & mean & Std. Dev. & & Mean & Std. Dev. & Mean & Std. Dev. \\
\hline Level of initial investment (yuan) & 88310 & 109712 & & 34723 & 98179 & 50425 & 108050 \\
\hline \% can be borrowed from formal financial instit. & 0.12 & 0.20 & & 0.02 & 0.11 & 0.04 & 0.19 \\
\hline \% can be borrowed from informal financ. Instit. & 0.05 & 0.10 & & 012 & 72 0 & 011 & 72 0 \\
\hline$\%$ can be borrowed from relatives and friends & 0.27 & 0.28 & & 0.12 & 0.21 & 0.14 & 0.21 \\
\hline$\%$ can be borrowed in all channels & 0.42 & 0.34 & & 0.17 & 0.32 & 0.27 & 0.38 \\
\hline
\end{tabular}

Note: The level of initial investment for the current entrepreneurs is in real terms using provincial CPI (1995=100) 
Table 7: Initial investment and investment gap

\begin{tabular}{|c|c|c|c|c|}
\hline & \multicolumn{2}{|c|}{$\log$ (initial investment) } & \multicolumn{2}{|c|}{$\begin{array}{l}\text { Level of investment unable to borrow } \\
\text { (want-to-be) }\end{array}$} \\
\hline & $\begin{array}{l}\text { Want-to-be } \\
\text { entrepreneurs }\end{array}$ & $\begin{array}{l}\text { Current } \\
\text { entrepreneurs }\end{array}$ & OLS & Tobit \\
\hline & [1] & {$[2]$} & [3] & {$[4]$} \\
\hline \multirow[t]{2}{*}{ Credit constraining events } & & & $5,454^{*}$ & $6,290 *$ \\
\hline & & & {$[2,934]$} & {$[3,276]$} \\
\hline \multirow[t]{2}{*}{ Age/10 } & 0.225 & 0.139 & -10512 & -11201 \\
\hline & [0.209] & {$[0.360]$} & {$[9,385]$} & {$[10,511]$} \\
\hline \multirow[t]{2}{*}{$(\text { Age } / 10)^{2}$} & -0.029 & -0.033 & 2134 & 2223 \\
\hline & [0.029] & [0.047] & {$[1,326]$} & {$[1,483]$} \\
\hline \multirow[t]{2}{*}{ Year since migration/10 } & $0.212^{*}$ & 0.196 & 4898 & 6495 \\
\hline & {$[0.126]$} & {$[0.230]$} & {$[5,702]$} & {$[6,446]$} \\
\hline \multirow[t]{2}{*}{$(\text { Year since migration } / 10)^{2}$} & -0.073 & 0.032 & -3539 & -4299 \\
\hline & [0.059] & {$[0.086]$} & {$[2,672]$} & {$[3,033]$} \\
\hline \multirow[t]{2}{*}{ Year of schooling } & $0.041 * * *$ & $0.080 * * *$ & -1023 & $-1,240 * *$ \\
\hline & {$[0.010]$} & {$[0.017]$} & {$[468]$} & {$[523]$} \\
\hline \multirow[t]{2}{*}{ Dummy for males } & $0.188 * * *$ & -0.081 & -4373 & $-4,956^{*}$ \\
\hline & {$[0.050]$} & [0.081] & {$[2,258]$} & {$[2,528]$} \\
\hline \multirow[t]{2}{*}{ Dummy for married } & 0.029 & 0.037 & -1815 & -1773 \\
\hline & [0.068] & {$[0.155]$} & {$[3,054]$} & {$[3,418]$} \\
\hline \multirow[t]{2}{*}{ Self assessed risk } & $0.030 * * *$ & $0.042 * *$ & -665 & $-987^{*}$ \\
\hline & {$[0.010]$} & {$[0.018]$} & [458] & {$[514]$} \\
\hline \multirow[t]{2}{*}{ Believe most people can be trusted } & -0.016 & 0.100 & -194 & 610 \\
\hline & {$[0.051]$} & {$[0.091]$} & {$[2,278]$} & {$[2,557]$} \\
\hline \multirow[t]{2}{*}{ Network in cities } & 0.014 & 0.028 & -2662 & -3632 \\
\hline & {$[0.013]$} & {$[0.027]$} & {$[577]$} & {$[689]$} \\
\hline \multirow[t]{2}{*}{ Hometown housing value $/ 10^{4}$} & $0.010 * * *$ & $0.009 * *$ & 64 & 42 \\
\hline & {$[0.003]$} & {$[0.004]$} & {$[148]$} & {$[165]$} \\
\hline \multirow[t]{2}{*}{ Level of initial investment } & & & $0.788 * * *$ & $0.805^{* * *}$ \\
\hline & & & {$[0.010]$} & {$[0.011]$} \\
\hline Dummies for starting year & & Yes & & \\
\hline City dummies & Yes & Yes & Yes & Yes \\
\hline Observations & 1334 & 1297 & 1334 & 1334 \\
\hline R-squared (Pseudo R-squared) & 0.10 & 0.15 & 0.84 & 0.07 \\
\hline LR chi2 & & & & 2133.19 \\
\hline
\end{tabular}

*** $\mathrm{p}<0.01, * * \mathrm{p}<0.05, * \mathrm{p}<0.1 ;$ Standard errors in brackets

Note: The level of initial investment for the current entrepreneurs is in real terms using provincial CPI (1995=100) 
Table 8: Projected welfare effect of the credit constraints

\begin{tabular}{|c|c|c|c|c|c|}
\hline & & Annual Effect & $\begin{array}{l}\text { As \% of mig } \\
\text { annual } \\
\text { earnings }\end{array}$ & $\begin{array}{l}\% \text { increase in } \\
\text { mig earnings }{ }^{B}\end{array}$ & $\begin{array}{l}\text { Annual increase } \\
\text { in urban } \\
\text { earnings }{ }^{c}\end{array}$ \\
\hline Based on Table $3 b$ & $=1.656 * 75 * 50$ & 6210 & 28.41 & 6.45 & 2.13 \\
\hline Based on $\beta$ diff. from sep. equ. & $=4.29 * 75 * 50$ & 16087.5 & 73.59 & 16.71 & 5.56 \\
\hline Based on self-predictions & $=(10.34-7.33) * 75 * 50$ & 11287.5 & 51.64 & 11.72 & 3.87 \\
\hline
\end{tabular}

Notes: A. Migrant total annual earning is 21860 yuan. B. $22.7 \%$ of migrants are want-to-be entrepreneurs; C. One third urban labours are migrants \& they earn one-third of urban workers annual pay. 
Table 9: Differential treatment of migrants and entrepreneruship by cities

\begin{tabular}{|c|c|c|c|c|}
\hline \multirow{3}{*}{ Panel A: } & \multicolumn{2}{|c|}{ City level regression } & \multicolumn{2}{|c|}{ Mean proportion by city } \\
\hline & Model 1 & Model 3 & $\%$ want-to-be & $\begin{array}{l}\% \text { of want-to-be } \\
\text { plus entre. }\end{array}$ \\
\hline & {$[1]$} & {$[2]$} & [3] & {$[4]$} \\
\hline \multirow[t]{2}{*}{ Guangzhou } & -0.530 & -0.515 & 0.35 & 0.43 \\
\hline & {$[0.051]^{* * *}$} & {$[0.054]^{* * *}$} & & \\
\hline \multirow[t]{2}{*}{ Dongguan } & -0.511 & -0.537 & 0.40 & 0.41 \\
\hline & {$[0.066]^{* * *}$} & {$[0.070]^{* * *}$} & & \\
\hline \multirow[t]{2}{*}{ Shenzhen } & -0.530 & -0.431 & 0.42 & 0.46 \\
\hline & {$[0.083]^{* * *}$} & {$[0.084]^{* * *}$} & & \\
\hline \multirow[t]{2}{*}{ Zhengzhou } & -0.531 & -0.500 & 0.43 & 0.60 \\
\hline & {$[0.080]^{* * *}$} & {$[0.081]^{* * *}$} & & \\
\hline \multirow[t]{2}{*}{ Luoyang } & -0.442 & -0.411 & 0.35 & 0.59 \\
\hline & {$[0.092]^{* * *}$} & {$[0.097]^{* * *}$} & & \\
\hline \multirow[t]{2}{*}{ Hefei } & -0.176 & -0.173 & 0.30 & 0.51 \\
\hline & {$[0.057]^{* * *}$} & {$[0.060]^{* * *}$} & & \\
\hline \multirow[t]{2}{*}{ Bangbu } & 0.001 & -0.047 & 0.28 & 0.48 \\
\hline & [0.092] & {$[0.100]$} & & \\
\hline \multirow[t]{2}{*}{ Chongqing } & -0.433 & -0.416 & 0.36 & 0.47 \\
\hline & {$[0.043]^{* * *}$} & {$[0.047]^{* * *}$} & & \\
\hline \multirow[t]{2}{*}{ Shanghai } & -0.392 & -0.345 & 0.17 & 0.43 \\
\hline & {$[0.050]^{* * *}$} & {$[0.052]^{* * *}$} & & \\
\hline \multirow[t]{2}{*}{ Nanjing } & -0.216 & -0.157 & 0.15 & 0.27 \\
\hline & {$[0.054]^{* * *}$} & {$[0.061]^{* * *}$} & & \\
\hline \multirow[t]{2}{*}{ Wuxi } & -0.071 & -0.050 & 0.09 & 0.26 \\
\hline & {$[0.070]$} & {$[0.074]$} & & \\
\hline \multirow[t]{2}{*}{ Hangzhou } & -0.510 & -0.484 & 0.40 & 0.53 \\
\hline & {$[0.048]^{* * *}$} & {$[0.051]^{* * *}$} & & \\
\hline \multirow[t]{2}{*}{ Ningbo } & -0.512 & -0.440 & 0.35 & 0.42 \\
\hline & {$[0.070]^{* * *}$} & {$[0.070]^{* * *}$} & & \\
\hline \multirow[t]{2}{*}{ Wuhan } & -0.396 & -0.381 & 0.34 & 0.48 \\
\hline & {$[0.048]^{* * *}$} & {$[0.054]^{* * *}$} & & \\
\hline \multirow[t]{2}{*}{ Chengdu } & -0.182 & -0.114 & 0.28 & 0.43 \\
\hline & {$[0.053]^{* * *}$} & {$[0.061]^{*}$} & & \\
\hline Panel B: & Constant & Coefficient & R-squared & No. of obs. \\
\hline \multirow[t]{2}{*}{ Regression columns [2] and [3]: } & 0.165 & -0.404 & 0.52 & 15 \\
\hline & {$[0.043]^{* * *}$} & {$[0.107]^{* * *}$} & & \\
\hline \multirow{2}{*}{ Regression columns [2] and [4]: } & 0.374 & -0.216 & 0.17 & 15 \\
\hline & {$[0.053]$} & {$[0.131]^{*}$} & & \\
\hline
\end{tabular}


Figure 1: Relationship between self-assessed and experimental measures of risk loving and trusting
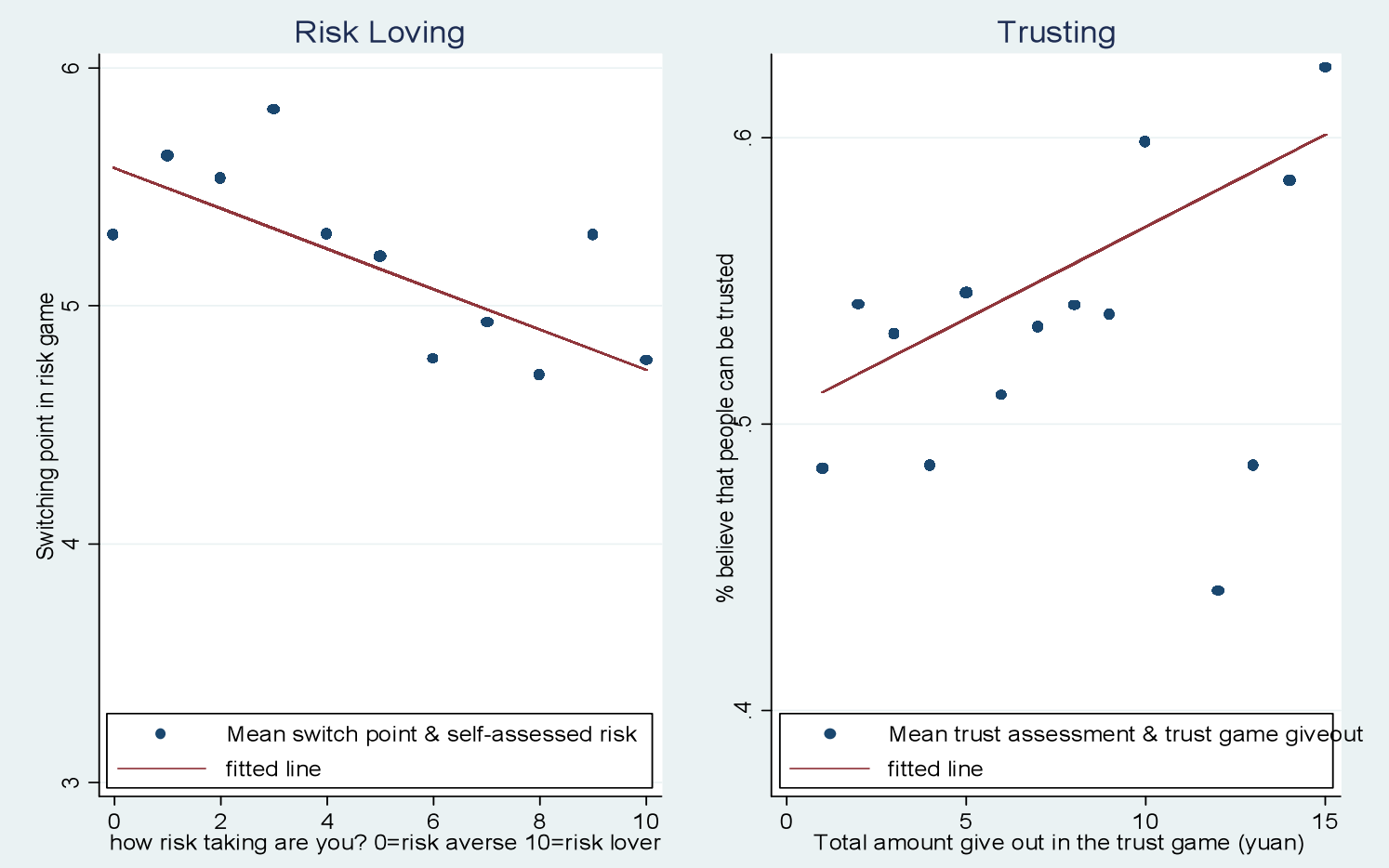
Figure 2: Distribution of the log initial investment in real term for current entrepreneurs and log expected initial investment for want-to-be entrepreneurs

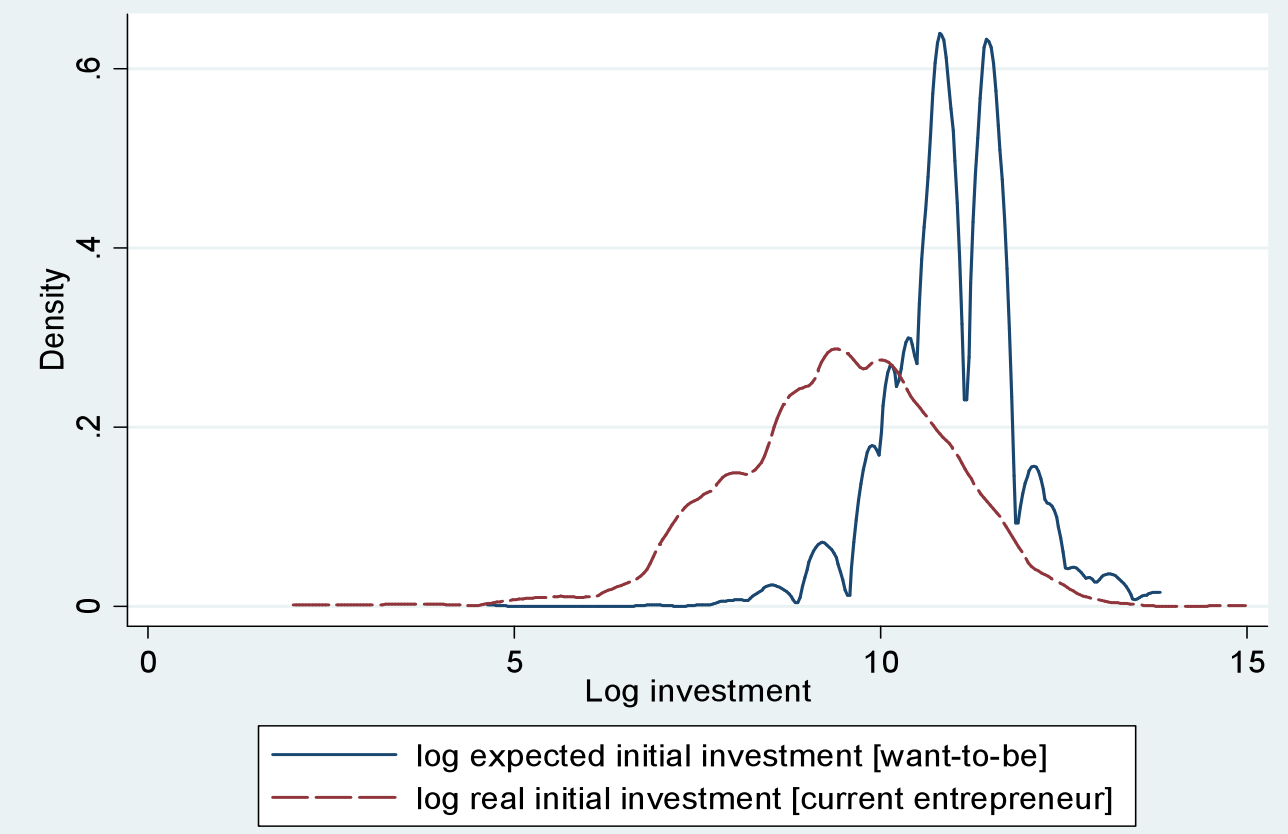


Figure 3: Initial investment and proportion borrowed by year of start of the business
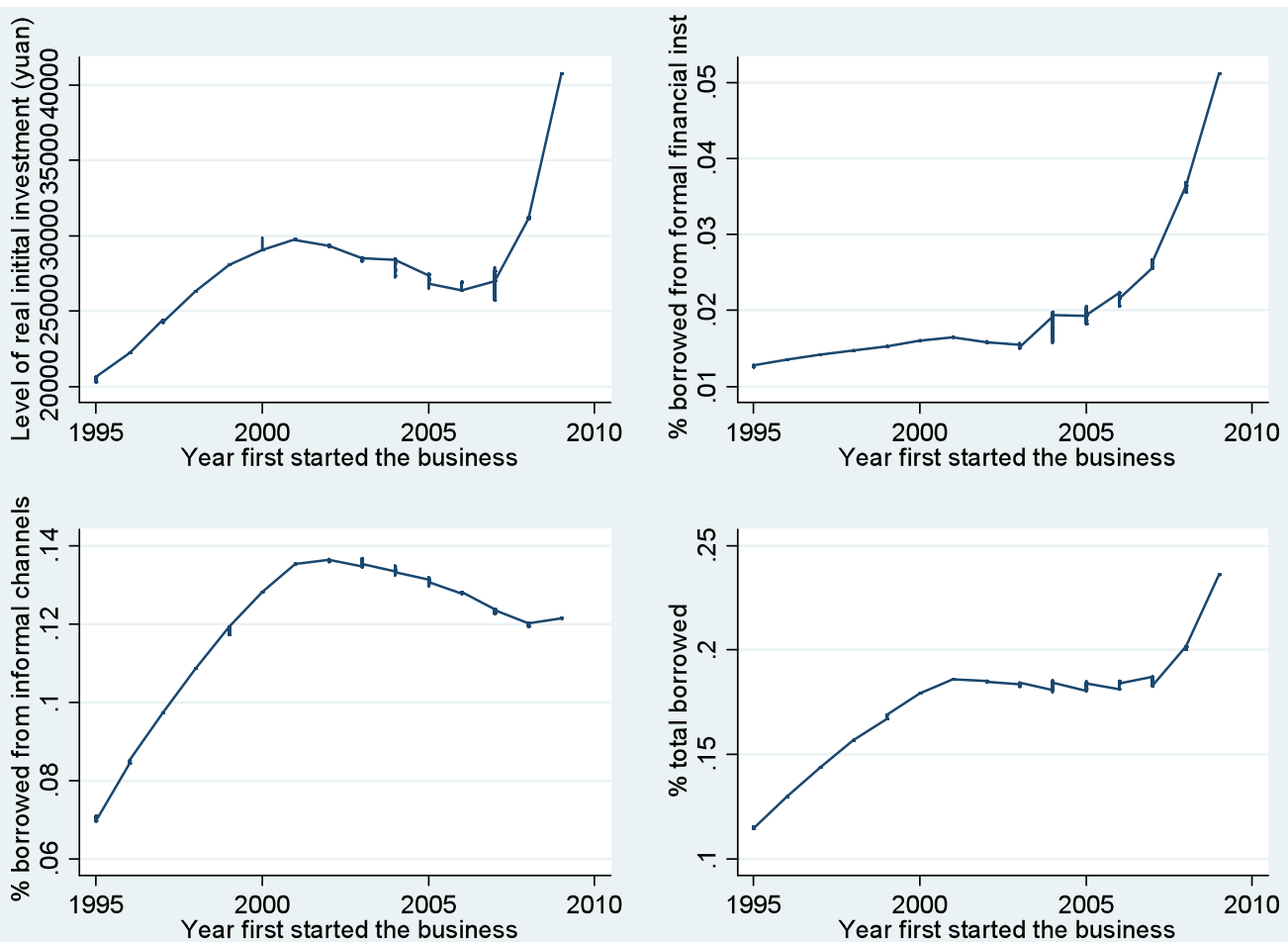


\section{Appendix A: The precise relevant questions in the survey}

\section{A1: Questions used to define "entrepreneurs":}

1. Why did you become self-employed?

(1) Cannot find a wage-salaried job;

(2) I can make more money being self-employed;

(3) I want to be my own boss;

(4) Self-employment gives me more freedom;

(5) Others (please explain).

2. Are you currently still looking for a wage-salaried job?

(1) Yes;

(2) No.

3. If you answered Yes to the above question, could you please tell us the reason?

(1) I can make more money in a wage-salaried job;

(2) Wage-salaried job maybe more respectable;

(3) Wage-salaried job maybe more stable;

(4) Others (please explain).

\section{A2: Questions used to define "want-to-be entrepreneurs":}

1. For wage-salaried workers: Have you ever thought about becoming a self-employed?

(1) No, never;

(2) Have not though carefully as it seems to be too difficult;

(3) Yes, I have thought (carefully) about it.

2. If you have thought about it, what stopped you from becoming one?

(1) Cannot borrow enough money;

(2) Do not have a network for obtaining a permit and/or customers;

(3) A self employed job is too hard;

(4) The income for self-employment is too low;

(5) Others (please explain).

\section{A3: General Health Questions:}

To what extent have you experienced each of the following during the past few weeks. Please chooses one of four options (measuring the frequency or severity of the experience):

(1) loss of concentration; 
(2) loss of sleep;

(3) playing a useful role;

(4) capable of making decisions;

(5) constantly under strain;

(6) problems overcoming difficulties;

(7) enjoy day-to-day activities;

(8) ability to face problems;

(9) unhappy or depressed;

(10) losing confidence;

(11) believe in self-worth;

(12) general happiness.

\section{Appendix B: Some details on the experiments}

The experiment takes as its underlying sample the migrant survey of the 2009 RUMiCI data, i.e. 5,123 migrant households from 15 cities in China in 2009. Each of these migrants was sent a call/text from the RUMiCI survey team to participate in experiments. They were given a choice of dates and times to come to 'the lab', which in most cities was a school class-room in the city centre. Subjects were told that they would receive 50 Yuan to compensate them for transportation costs, and that the experiments would take approximately 2.5 hours, with the total compensation depending on their performance in the experiments. The average participant was compensated the equivalent of one and half day's pay (100 Yuan). About one third of the survey respondents showed up, making up the 1,656 individuals in the experimental sample. Consistency of instructions was guaranteed by using a video recording.

The 1,656 subjects all participated in 4 activities (apart from instructions and registration): 3 modules on risk-aversion, time-preference and trust, and one IQ test in the middle of those experiments. The IQ test was a 30-minute nonverbal test- Raven's Standard Progressive Matrices (RSPM).

The risk-aversion module used real monetary payoffs and asked participants to choose between lotteries. Lottery 1 for instance asks a participant to choose between either option A (the safe option) where a respondent would get 15 Yuan for sure, or option B that represented a 50\% chance of 20 Yuan and a $50 \%$ chance of receiving 0 Yuan. Option A remains the same in lottery 2 , but the payoff in option B is higher. In lottery 3 the payoff to option B is higher still, and this increase is maintained untill lottery 11. Subjects are told that one out of the 11 lotteries is actually going to be played at random and they are asked to decide on the lowest lottery where they would choose 
option B. Hence a higher switching point would denote a higher degree of risk-aversion.

Time-preferences are measured in an analogue manner, with individuals asked to choose between a payoff now or a payoff in the future and the payoff in the future increasing over options. The respondent is asked at which point he/she would accept the future payoff and a higher switching point would indicate a higher discount rate.

Trust and trustworthiness is measured using the Burks et al (2003) set-up. Each participants is firstly asked to send anything between 0 and 15 yuan to a returner. The returner would receive 3 times the amount sent by the sender and would then be asked how much to return to the sender (anything between 0 and the amount received). Whilst each subject is both sender and returner, senders are only told they will be a receiver after they have made the decision on how much to send (the sender is not matched to the same person as returner). The amount the sender sends is our measure for trust, whilst the percentage returned a measure of trustworthiness or reciprocity. Burks et al (2003) argue that if senders are not informed beforehand about their future role as a returner, then the two-role game begets the same results as a 1-role game. 


\section{Appendix C:}

Regressions by self-employed and wage-salary groups

\begin{tabular}{|c|c|c|c|c|}
\hline & $\begin{array}{l}\text { Wage-salary } \\
\text { earners }\end{array}$ & Self-employed & $\begin{array}{l}\text { Want-to-be } \\
\text { entrepreneurs }\end{array}$ & $\begin{array}{l}\text { Current } \\
\text { entrepreneurs }\end{array}$ \\
\hline \multirow[t]{2}{*}{ Age } & 0.374 & 0.292 & 0.354 & 0.336 \\
\hline & {$[0.045]^{* * *}$} & {$[0.242]$} & {$[0.105]^{* * *}$} & [0.289] \\
\hline \multirow[t]{2}{*}{ Age2 } & -0.005 & -0.004 & -0.006 & -0.005 \\
\hline & {$[0.001]^{* * *}$} & [0.003] & {$[0.001]^{* * *}$} & [0.004] \\
\hline \multirow[t]{2}{*}{ Years of schooling } & 0.398 & 0.209 & 0.365 & 0.191 \\
\hline & {$[0.027]^{* * *}$} & {$[0.123]^{*}$} & {$[0.055]^{* * *}$} & [0.149] \\
\hline \multirow[t]{2}{*}{ Dummy for males } & 1.454 & 2.104 & 1.474 & 2.614 \\
\hline & {$[0.137]^{* * *}$} & {$[0.587]^{* * *}$} & {$[0.275]^{* * *}$} & {$[0.697]^{* * *}$} \\
\hline \multirow[t]{2}{*}{ Dummy for married } & 0.434 & -0.355 & 0.635 & -0.049 \\
\hline & {$[0.184]^{* *}$} & [1.149] & {$[0.355]^{*}$} & [1.314] \\
\hline \multirow[t]{2}{*}{ Risk loving } & 0.031 & 0.241 & -0.05 & 0.249 \\
\hline & {$[0.027]$} & {$[0.131]^{*}$} & [0.053] & [0.155] \\
\hline \multirow[t]{2}{*}{ Trusting } & -0.025 & 0.958 & -0.46 & 1.238 \\
\hline & {$[0.140]$} & {$[0.667]$} & {$[0.268]^{*}$} & [0.797] \\
\hline \multirow[t]{2}{*}{ Size of the social network in the city } & 0.027 & 0.114 & 0.022 & 0.116 \\
\hline & {$[0.004]^{* * *}$} & {$[0.020]^{* * *}$} & {$[0.007]^{* * *}$} & {$[0.024]^{* * *}$} \\
\hline Industry dummies & Yes & Yes & Yes & Yes \\
\hline Region & Yes & Yes & Yes & Yes \\
\hline Observations & 4884 & 1905 & 1541 & 1563 \\
\hline R-squared & 0.20 & 0.08 & 0.18 & 0.09 \\
\hline
\end{tabular}

*** $\mathrm{p}<0.01, * * \mathrm{p}<0.05, * \mathrm{p}<0.1 ;$ Standard errors in brackets

Note: Initial investment is excluded from this regression as wage-salary earners do not have this information. 